\title{
Evolution of regional to global paddy rice mapping methods: A review
}

$$
\text { Jinwei Dong }^{1 *} \text { and Xiangming Xiao }{ }^{1,2^{*}}
$$

${ }^{1}$ Department of Microbiology and Plant Biology, and Center for Spatial Analysis, University of Oklahoma, Norman, OK, 73019, USA;

${ }^{2}$ Institute of Biodiversity Science, Fudan University, Shanghai, 200433, China.

\section{* Corresponding Authors:}

Xiangming Xiao, 101 David L. Boren Blvd. Norman, OK 73019, USA

Email: xiangming.xiao@ ou.edu; Phone: +1-(405)325-8941

Jinwei Dong, 101 David L. Boren Blvd. Norman, OK 73019, USA

Email: Jinwei.dong@ou.edu; Phone: +1-(405)325-6091

Journal to submit: ISPRS journal of P\&RS ( $1^{\text {st }}$ Revision $)$ 
Abstract: Paddy rice agriculture plays an important role in various environmental issues including food security, water use, climate change, and disease transmission. However, regional and global paddy rice maps are surprisingly scarce and sporadic despite numerous efforts in paddy rice mapping algorithms and applications. With the increasing need for regional to global paddy rice maps, this paper reviewed the existing paddy rice mapping methods from the literatures ranging from the 1980s to 2015 . In particular, we illustrated the evolution of these paddy rice mapping efforts, looking specifically at the future trajectory of paddy rice mapping methodologies. The biophysical features and growth phases of paddy rice were analyzed first, and feature selections for paddy rice mapping were analyzed from spectral, polarimetric, temporal, spatial, and textural aspects. We sorted out paddy rice mapping algorithms into four categories: 1) Reflectance data and image statistic-based approaches, 2) vegetation index (VI) data and enhanced image statisticbased approaches, 3) VI or RADAR backscatter-based temporal analysis approaches, and 4) phenology-based approaches through remote sensing recognition of key growth phases. The phenology-based approaches using unique features of paddy rice (e.g., transplanting) for mapping have been increasingly used in paddy rice mapping. Current application of these phenology-based approaches generally use coarse resolution MODIS data, which involves mixed pixel issues in Asia where smallholders comprise the majority of paddy rice agriculture. The free release of Landsat archive data and the launch of Landsat 8 and Sentinel-2 are providing unprecedented opportunities to map paddy rice in fragmented landscapes with higher spatial resolution. Based on the literature review, we discussed a series of issues for large scale operational paddy rice mapping. Keywords: Paddy rice mapping, algorithms, review, MODIS, Landsat, phenology, SAR 


\section{Introduction}

Food security is always a big challenge due to the continuously increasing population and limited land, especially given that the global population is expected to reach around 9 billion in 2050 from 7 billion in 2010. As a major staple, rice feeds almost half of the world's population (Kuenzer and Knauer, 2013) and provides $19 \%$ of the daily human energy supply as the firstranked cereal type (Elert, 2014). Paddy rice areas account for more than $12 \%$ of global cropland area (FAOSTAT, 2010) and are increasing remarkably, especially in Africa with diets shifting to include more rice. Asia has the largest paddy rice fields (Maclean and Hettel, 2002) and produced more than $90 \%$ of global rice in 2011 (Kuenzer and Knauer, 2013), while Africa and Europe need to import rice from other countries (Elert, 2014). Therefore, paddy rice maps are necessary for understanding and assessing the status of food security at regional, national, and global scales.

In addition, paddy rice also plays an important role in other environmental issues including water use, climate change, and disease transmission. Paddy rice planting is an important source of water use. Around one-fourth to one-third of the world's developed freshwater resources are used for rice irrigation as the production of $1 \mathrm{~kg}$ of rough rice needs about $2500 \mathrm{~L}$ of water (Bouman, 2009). The improvement of water-use efficiency in rice agriculture would greatly benefit global water resource protection. Measuring water resource consumption from rice agriculture requires spatially explicit information on paddy rice distribution and dynamics.

Paddy rice agriculture also affects climate change through exchange of greenhouse gases and water flux. Flooded paddies for rice planting yield large amounts of evapotranspiration that change land surface energy balance through changing latent heat. Accurate estimation of actual evapotranspiration in the agricultural landscapes needs high quality paddy rice maps. Paddy rice fields are also important sources of methane $\left(\mathrm{CH}_{4}\right)$ emission (Sass et al., 1999). Global emissions 
of rice-based methane account for more than $10 \%$ of the total $\mathrm{CH}_{4}$ flux in the atmosphere (Ehhalt et al., 2001; Sass and Cicerone, 2002). $\mathrm{CH}_{4}$ is the second important greenhouse gas following $\mathrm{CO}_{2}$; however, its capability is 28 times that of $\mathrm{CO}_{2}$. Previous studies estimated global $\mathrm{CH}_{4}$ emission but with a large uncertainty (ranged from $\sim 14.8$ to $100 \mathrm{Tg} \mathrm{a}^{-1}$ ) (Yan et al., 2009; Yan et al., 2003) that was found to be related to the reliability of the information regarding the amount of organic amendments and the area of paddy rice fields (Yan et al., 2009).

Besides its effects on food security, water resource use, and climate change, paddy rice agriculture is also related to the transmission of disease such as highly pathogenic avian influenza A (H5N1) virus (Gilbert et al., 2008), as paddy rice fields are an important habitat for free-ranging ducks and wild waterfowl in winter and a prime location for transmission of the avian influenza virus (Gilbert et al., 2014; Gilbert et al., 2008). In sum, it is important to monitor and map paddy rice fields at regional and global scales in an effort to enhance our knowledge of a series of environmental issues.

Clearly, knowledge of area, distribution and dynamics of paddy rice is important for decisionmaking and academic studies related to paddy rice. However, as far as we know, there are no available global paddy rice maps or temporally continuous regional scale maps up to date, which is a source of the uncertainties in estimating methane emissions (van Groenigen et al., 2013; Yan et al., 2009), water use (Tao et al., 2008), natural wetland loss in some regions (Wang et al., 2010; Wang et al., 2011b), and other environmental issues (Figure 1). 


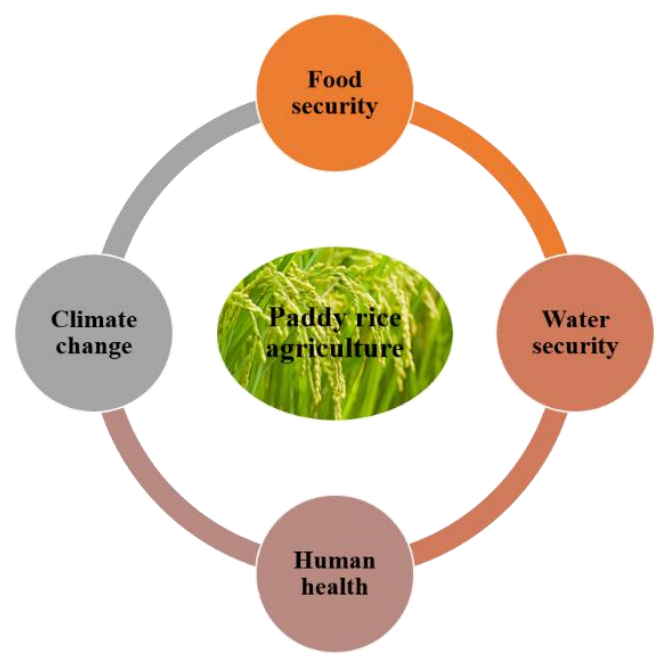

Figure 1 Simple conceptual diagram about the significance of paddy rice agriculture.

Many efforts have been made in paddy rice mapping by using various algorithms (e.g, supervised classifiers, unsupervised classifiers, knowledge-based approaches, and phenologybased classifiers) as well as different data sources including optical remote sensing (e.g., SPOTVGT, MODIS, and Landsat) and microwave remote sensing (e.g., RADARSAT, PALSAR). A synthesis analysis of existing paddy rice mapping algorithms would contribute to the development of a universal mapping approach and its extensive application. To cultivate global paddy rice mapping efforts, this study aims to review the existing paddy rice mapping algorithms from the literatures since 1987. The review paper is organized into six sections. We first analyzed the significance of paddy rice maps in Section 1. In Section 2, we briefly analyzed the status quo of paddy rice maps. In Section 3, we summarized biophysical features of paddy rice fields throughout its major growing stages and their potential applications on paddy rice mapping. In Section 4, the evolution of paddy rice mapping methods was systematically analyzed and the existing methods were divided into four categories. In Section 5, we discussed current challenges and opportunities in future global/regional paddy rice mapping. Section 6 concluded the major findings and implications in the context of large scale applications. 


\section{Existing paddy rice maps at national or larger scales}

Global cropland layers have been generated and categorized from land cover products such as MODIS-based MCD12Q1 (Friedl et al., 2002), MERIS-based GlobCover (Bontemps et al., 2011), MERIS and SPOT-VGT based CCI-LC (Kirches et al., 2014), Landsat-based FROM-GLC (Gong et al., 2013), and Global Land Cover based on the integration of pixel- and object-based methods with knowledge (Chen et al., 2015). In addition, global cropland maps have also been generated thematically; for example, 30-m Landsat-based FROM-GC (Yu et al., 2013), as well as a 1-km global IIASA-IFPRI cropland percentage map through integrating existing global and regional products (Fritz et al., 2015). However, paddy rice-specific maps are still unavailable. Existing global paddy rice maps are generally produced using statistical approaches (Frolking et al., 2002; Huke et al., 1997; Leff et al., 2004; Monfreda et al., 2008).

On sub-continental scales, some efforts of paddy rice mapping have been made including South Asia (Gumma et al., 2011; Xiao et al., 2006) and Southeast Asia (Bridhikitti and Overcamp, 2012; Kuenzer and Knauer, 2013), northeastern Asia (Dong et al., 2016a; Dong et al., 2016b), as well as on the national scales, like the Landsat-based Cropland Data Layer (CDL) in the USA (Johnson and Mueller, 2010) and MODIS-based paddy rice maps of India, China and Bangladesh (Gumma et al., 2014; Sun et al., 2009; Xiao et al., 2005). A recent paddy rice map was released for monsoon Asia however, it was not validated (Figure 2) (Nelson and Gumma, 2015). Therefore, all these efforts generally have limited spatial and temporal coverages. There is still no operational paddy rice mapping approach for larger scale or global efforts; and these existing paddy rice maps are only on static images and no systematic or temporal dynamic information is available. In addition, the existing efforts show a remarkable discrepancy on paddy rice areas (Appendix Table A1). 


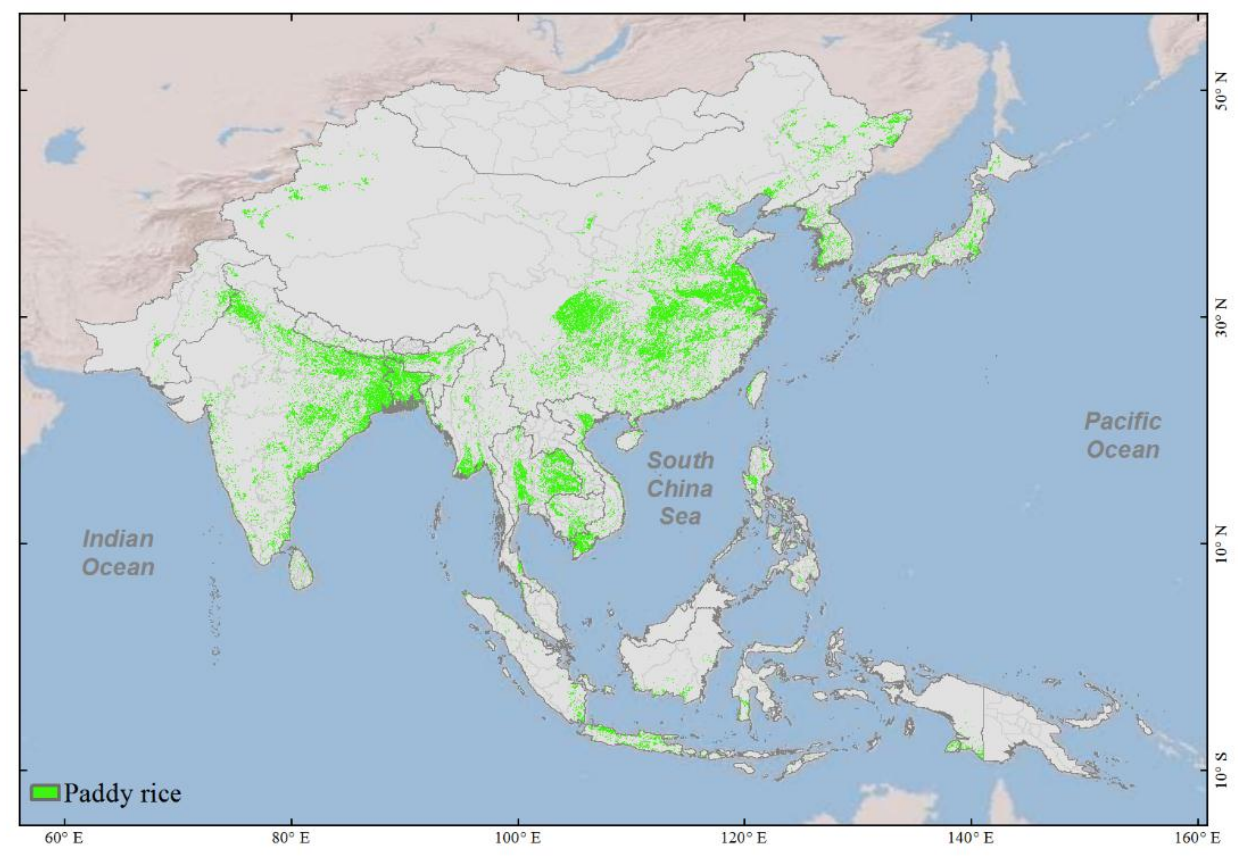

Figure 2. Paddy rice distribution in monsoon Asia, where over $90 \%$ of rice in the world is produced. The map is derived from the International Rice Research Institute (IRRI) (Nelson and Gumma, 2015).

\section{Biophysical features of paddy rice and its feature selection in remote sensing}

\subsection{Biophysical characteristics and growth phases of paddy rice}

Thorough comprehension of rice physiology and planting situations is the prerequisite of paddy rice mapping. Not only do the general physical features of various crops differ, but also the characteristics of rice in varied growing phases diverge (Chang et al., 2005). The growing phases of paddy rice can be divided into four stages according to Brouwer et al. (1989): 1) the nursery stage from sowing to transplanting ( 1 month), 2) the vegetative stage from transplanting to panicle initiation (1.5-3 months, including tillering), 3) the reproductive stage from panicle initiation to flowering $(\sim 1$ month, including stem elongation, panicle initiation, heading and flowering), and 4) the ripening stage from flowering to full maturity ( 1 month, including milk 
stage, dough stage, and mature grain) (Brouwer et al., 1989). Paddy rice is the only crop that needs abundant water in the growing stages; in particular, paddy rice is the only staple grain that needs to be transplanted, while winter wheat, corn, and soybean do not. Thus, the identification of paddy rice requires those spectral bands or indices that are sensitive to the mixture of water body, soil and vegetation. The temporal variation of water-soil-vegetation composition will be a critical factor in paddy rice identification (Figure 3). In addition, paddy rice fields need to have good drainage and irrigation conditions and that requires the size of one field to not be too big. Thus, field size could be a potential feature for paddy rice mapping; however, field stems could be mixed with crops when coarse resolution images are used.

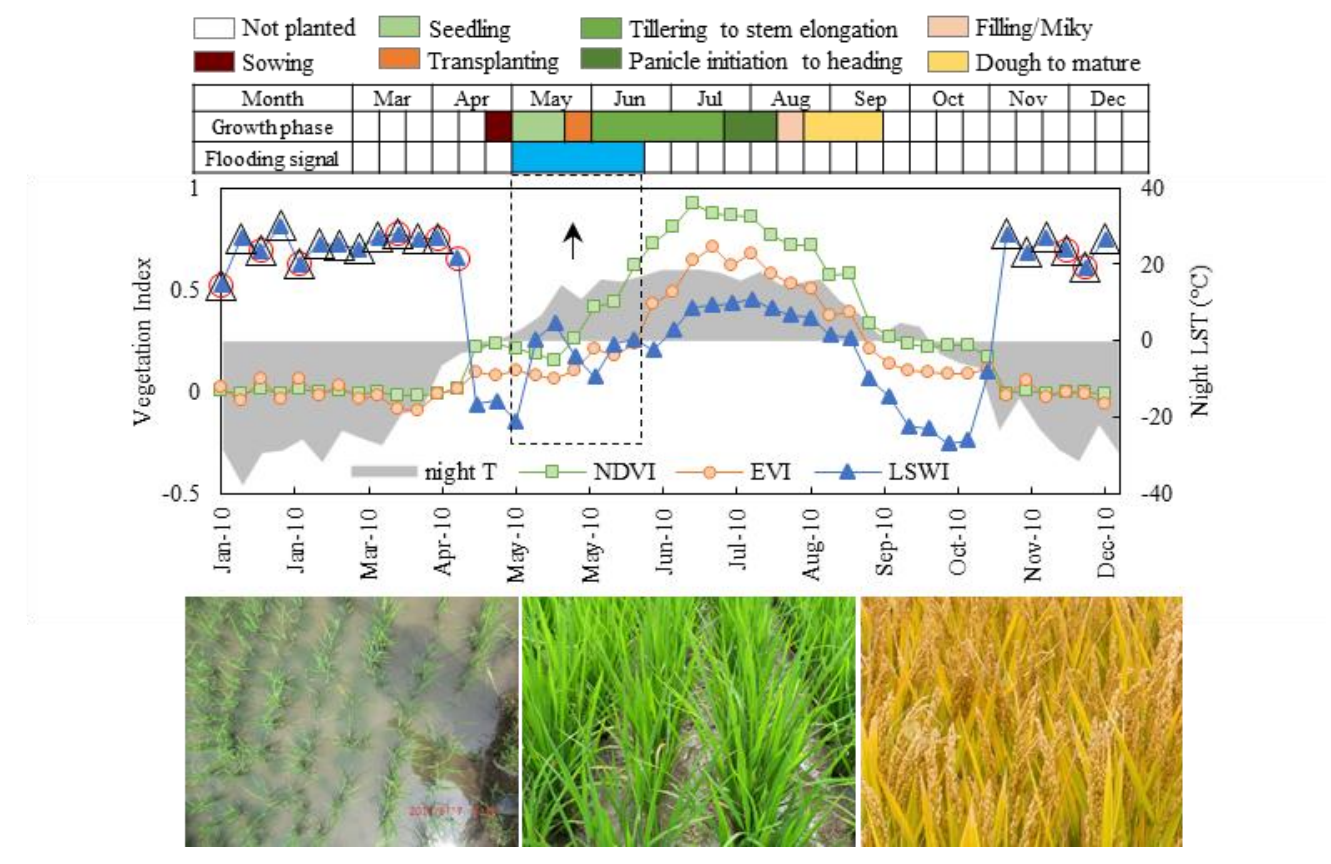

Figure 3. The key growth stages of paddy rice and remote sensing representation. The seasonal dynamics of three MODIS-based vegetation indices (NDVI, EVI, and LSWI) as well as the nighttime land surface temperature (LST) from a typical paddy rice site (Hulin Site, $132.825^{\circ} \mathrm{E}, 45.737^{\circ} \mathrm{N}$ ) in 2010 . The calendar information is derived from the agricultural phenological observations data. The below photos of show transplanting, tillering, and mature phases of rice farming. The hollow triangular and round symbols 
on the LSWI curves mean the snow/ice, clouds and cloud shadows from the MODIS quality layer and blue band $>=0.2$, respectively.

\subsection{Key feature selection for paddy rice extraction}

\subsubsection{Spectral features of paddy rice fields}

Paddy rice and other crops could have different spectral features by using hyperspectral remotely sensed data (Arafat et al., 2013); however, the direct discrimination of paddy rice and other crops based on one arbitrary phase is usually unreliable due to the similarity of their spectral characteristics (Wang et al., 2012) and the complexity of paddy rice under different cultivation conditions (Song et al., 2011). The spectral signatures of paddy rice are especially affected by the background soil and water conditions in early stages (Figure 3). The pure spectral feature-based paddy rice mapping efforts are stated in Section 4.1.

The reflectance spectra of paddy plants vary during different growth phases (Chang et al., 2005). Multi-temporal profile analysis of paddy rice features is widely used in existing paddy rice mapping efforts and generally utilizes temporal analysis of VIs (Qiu et al., 2015; Xiao et al., 2006; Xiao et al., 2005). For example, the Normalized Difference Vegetation Index (NDVI) and Enhanced Vegetation Index (EVI) show an increase and decrease variation respectively with a peak in the heading phase (Wang et al., 2011a). The Land Surface Water Index (LSWI) also shows a similar variation in the rice growth cycle but with a jump in the transplanting phase due to water inundation (Xiao et al., 2002) (Figure 3). The different VIs also have various sensitivities, for example, Motohka et al. (2009) found that EVI was superior to NDVI in terms of agreement with the in situ phenology data; Qiu et al. (2015) found the variation of LSWI was relatively smaller in rice than in other crops during the period from tillering to heading dates. The applications of temporal VIs in paddy rice mapping are described in Sections 4.2, 4.3, and 4.4. 


\subsubsection{Polarimetric features of paddy rice fields}

As lower frequency waves have longer lengths and deeper penetration capability in vegetation canopy, we can assume the longer bands (e.g., C- and L-bands) have stronger relationship with above ground biomass and LAI, while shorter band (e.g., X-band) can better examine shorter seedlings in early stages of paddy rice. Previous studies have verified this assumption. For example, Inoue et al. (2002) conducted a comprehensive experiment that observed all the backscatter signatures from five frequencies (Ka, Ku, X, C, and L-bands), all polarizations ( $\mathrm{HH}$, $\mathrm{VH}, \mathrm{HV}$, and $\mathrm{VV})$, and four incident angles $\left(25^{\circ}, 35^{\circ}, 45^{\circ}\right.$, and $\left.55^{\circ}\right)$ from pre-transplantation to post-harvest cultivation, and found LAI was best correlated with HH- and cross-polarization of the C-band, while fresh biomass was best correlated with HH- and cross-polarization of the L-band; other bands (Ka, Ku, X-bands) had no significant relationships with LAI or biomass. Suga and Konishi (2008) also compared the X-, C- and L-band backscatters from different sensors in the growth phase of paddy rice and found the shorter band performed better in the earlier growth phase. Thus, the shorter X-band was found superior to the C- and L-bands in detecting small rice seedlings as well as the panicle biomass and can be a strong indicator for rice grain yield simulation (Inoue et al., 2002; Inoue and Sakaiya, 2013). C-band and L-band show promising capabilities in LAI or fAPAR estimates for rice growth (Inoue et al., 2014) and paddy rice field mapping (Kurosu et al., 1995; Torbick et al., 2011). Furthermore, Wang et al (2009) and Yisok et al (2009) also found the L-band $\mathrm{HH}$ backscatter was more sensitive to rice structural variation and growth than the VV backscatter. Microwave data has been used for paddy rice mapping for a long time and more details were described in Section 4. 


\subsubsection{Field shape and size features of paddy rice fields}

As paddy rice grows in bounded flooded fields, the field size should be controlled and overlarge fields would increase the operational difficulty of irrigation management. That feature would be useful for the object-based classification approach. The shape and texture characteristics are also important variables. While the shapes of rice paddies may differ across regions (Figure 4), the textures of paddy rice fields are all uniform due to the homogeneous nature and morphology of paddy rice fields that can be characterized by using the mean, consistency, entropy, and correlation statistics. However, existing studies hardly used these features for paddy rice mapping. Shiu et al (2012) used the objects not from the images but from the GIS dataset for the post classification of paddy rice and proved the efficiency of the object-based approach in reducing the speckle or mixed pixels. As to textural information however, Kim and Yeom $(2012 ; 2014)$ found it only contributed to minor improvements or even a slight decline in paddy rice map accuracy. Further study and assessments in large scale areas and using different growth phase images are needed. A systematic assessment of the application of shape, field size, and texture information would contribute to more accurate paddy rice mapping. However, these information have been barely used in the existing efforts (Tables 1-4). 

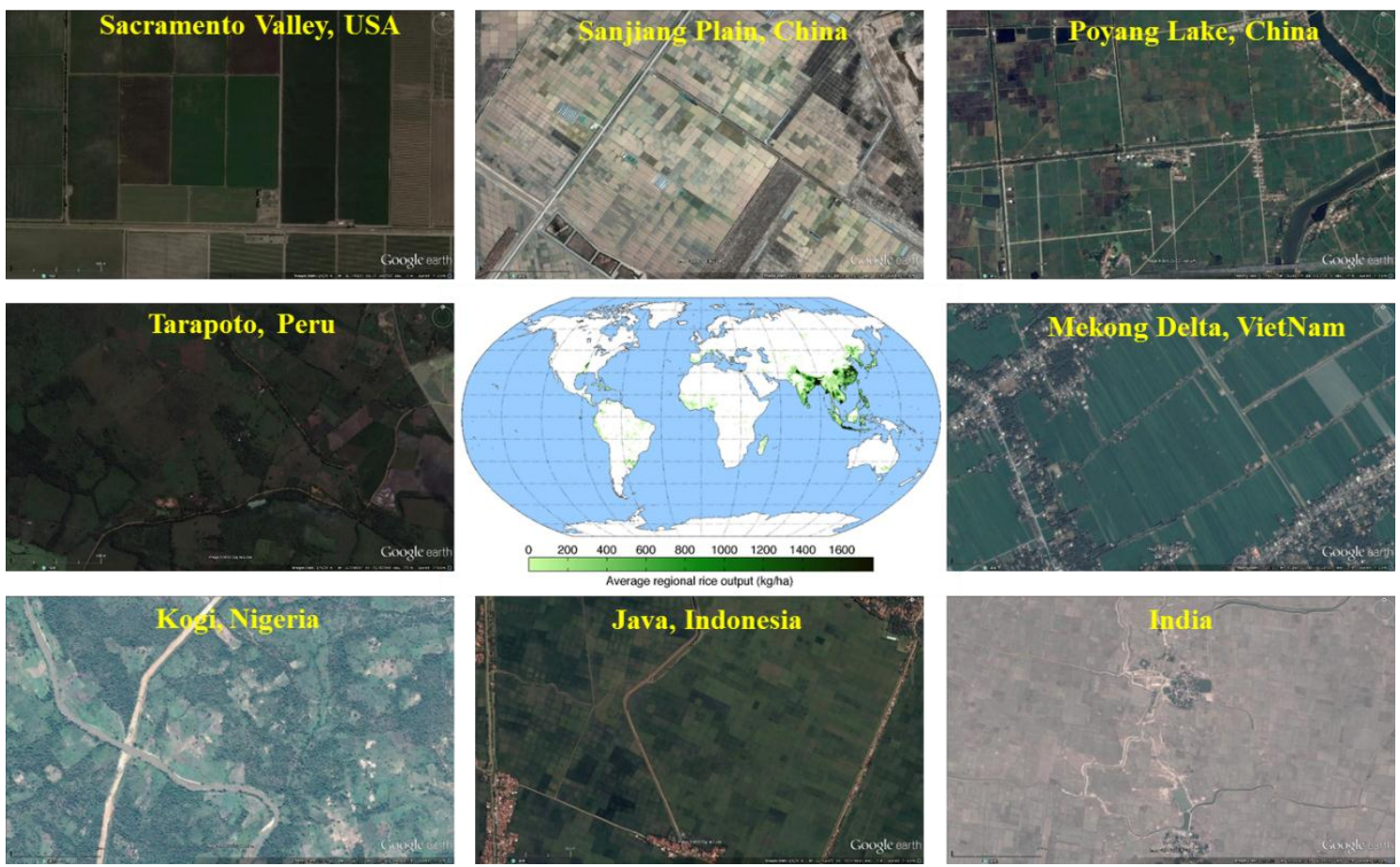

Figure 4. Selected paddy rice field samples for the globe with the same scale, which show the landscape differences among different regions. The central map shows the spatial distribution of rice production across the world in 2000, which was compiled by the University of Minnesota Institute on the Environment with data from Ramankutty et al. (2008).

\section{Evolution of paddy rice mapping algorithms}

\subsection{Category One: Reflectance data and image statistic-based approaches}

From the 1980s to the 1990s, Landsat MSS/TM was the major data source for paddy rice mapping, and the band reflectance were the major input data while the supervised and unsupervised classifiers were widely used for classification (Table 1). For example, early in 1987, Landsat MSS imagery was used to map paddy rice based on the band reflectance data by using the maximum likelihood classifier (MLC) and vector classifier (Mccloy et al., 1987), that study also indicated that the criteria for classification should be changed for different phenological stages of rice. Rao et al. (1987) also mentioned the importance of critical crop time windows for data 
acquisition, specifically, by identifying the period with minimum overlap of greenness between rice and other crops, and they successfully mapped rice in the pilot regions of India. Then Tennakoon et al. (1992) found that the spectral characteristics of paddy rice are subject to growth stages and highly influenced by soil moisture; furthermore, they found that, when using MLC approach, Landsat TM band combination 5/4/3 was an appropriate band combination for the identification and area estimation of rice at the maturity stage and bands 5/3/1 provided better information at the young stage of rice. However, Panigrahy and Parihar (1992) found the Landsat TM band 2/3/4/5 and 2/3/4/7 performed better than the combination of TM band 1/2/3/4 by using the same approach (MLC). These explorations of reflectance data selection and its sensitivity to growth phases were still constrained however, by the temporally limited data. Besides the supervised MLC approach (Fang et al., 1998), unsupervised classification was also used for paddy rice mapping (Fang, 1998).

\section{[Table 1]}

Besides Landsat imagery, SPOT XS was also used for paddy rice mapping by using the images from pre-flood and the first half of the flood period in West Africa (Turner and Congalton, 1998). In addition to optical remote sensing, RADAR was another data source for paddy rice mapping by using similar approaches (MLC or unsupervised classifiers) including the ERS-1 C-band data (Kurosu et al., 1997) and JERS-1 L-band data (Okamoto and Kawashima, 1999). Through a multitemporal data analysis, Kurosu et al. (1997) found that flooded-field data are essential for identifying rice fields.

In sum, at the early stage of paddy rice mapping: 1) Landsat data were the major data source while other data sources (such as SPOT XS and ERS-1, JERS-1) were only used in rare cases due to limited data availability; 2) Traditional supervised and unsupervised classifiers, especially 
the MLC approach, were used for the studies; 3) Crop phenology and determination of a suitable period had been recognized as a vital feature for paddy rice mapping. However, the acquisition of Landsat and other data was still a big challenge due to the expensive price, data receiving capability at the moment, and frequent cloud coverage in rice planting regions. Furthermore, agricultural systems in tropical regions (e.g., South and Southeast Asia) are highly variable as the seedling and transplanting stages of paddy rice are subject to varied monsoon rain arrival times. Thus, although the data temporal window was generally well recognized at this stage, paddy rice mapping at a regional scale remained difficult.

\subsection{Category Two: VI and enhanced image statistic-based approaches}

Since 2000, new improvements in paddy rice mapping approaches have generally derived from two factors: 1) utilizing new classifiers, and 2) new data inputs from new types of data sources (e.g., MODIS) and inclusion of vegetation indices (VIs). First, some new classifiers were increasingly used for paddy rice mapping; for example, the neutral net (NN) classifier was used for paddy rice mapping by using multiple images from the transplanting, flowering, and harvest stages of paddy rice with high accuracy (91\%) (Shao et al., 2001). By involving more images, Chen and McNairn (2006) tested four methods (Neural network (NN), change detection (CC), integration of $\mathrm{NN}$ and $\mathrm{CC}$, and MLC) and found the integrated approach was most promising. They also mentioned that the radar backscatter increases significantly within a short growth period after transplanting, which can be used to separate paddy rice and other land covers. Besides NN, other methods were also increasingly used such as the Support Vector machine (SVM) (Li et al., 2014; Tan et al., 2007; Zhang et al., 2009). Zhang et al. (2009) used three PALSAR HH polarization images taken during transplanting, tillering, and heading phases with the SVM classifier and achieved a reasonably accurate paddy rice map. The advantage of SVM 
is in its robust capability to train sample numbers ( $\mathrm{Li}$ et al., 2015). A recent study found that application of SVM in complex landscapes is still challenging and proposed a combined supervised and unsupervised classification using a mixed-pixel decomposition model (Li et al., 2014). Tan et al. (2007) further improved the SVM method by involving an entropy decomposition (ED) model to generate the feature vectors.

Besides the improvement in classification approaches, data variables were also improved for paddy rice mapping. Reflectance data were the major source for paddy rice classifications in Category One; VIs, combinations of reflectance from two or more bands for signal enhancement for particular aims, provided further information for feature extraction of rice mapping. For example, NDVI (Rouse et al. 1974) and EVI (Huete et al., 2002) are two widely used indices for vegetation greenness. NDVI is sensitive to chlorophyll with responses in visible bands, it is also limited by saturation under closed canopy and soil background (Huete et al., 2002; Xiao et al., 2003), while EVI is more sensitive to NIR and robust to biomass variation (Cheng, 2006). Some water-related indices, e.g. Normalized Difference Water Index (NDWI) (Gao, 1996) and Land Surface Water Index (LSWI) (Xiao et al., 2002), were also very helpful for paddy rice mapping as paddy rice is planted in a water abundant environment. Since 2000, these VIs have been used frequently in paddy rice mapping efforts. These studies indicated that the transformation of optical remote sensing bands into vegetation indices (e.g, NDVI, EVI, LSWI, NDWI, and NDSI) could increase land cover/use classification accuracy when compared with the traditional classification techniques that used the original reflectance or digital number data (Oguro et al., 2001; Pan et al., 2010; Thi et al., 2012). A recent study showed a combined application of VIs was more promising than the utility of single index (Tornos et al., 2015). For example, by using three VIs (NDVI, NDWI, and NDSI) and a simple ISODATA unsupervised classifier, Pan et al. 
(2010) found that the VI-based approach is superior to the traditional classification methods based on the original un-transformed images.

In sum, the approaches in Category Two (Table 2) made great advances compared to Category One in three aspects: 1) More sophisticated classifiers (e.g., SVM, NN) were used. These new algorithms have been proved with improved accuracies compared to the traditional supervised and unsupervised approaches (e.g., MLC) (Chen and McNairn, 2006). However, the performance of these improved algorithms still relied on the data input and data acquisition time window. 2) Vegetation indices (e.g., NDVI, EVI, NDWI, and LSWI) became major data sources instead of the reflectance data in Category One, as VIs can effectively provide greenness, water content, and soil information. 3) The studies were more goal-oriented in using suitable temporal windows for paddy rice mapping. Table 2 showed that all the algorithms in this category were applied to the images in key phenological stages like transplanting, tillering, and harvest. Besides the multiple vegetation indices, hyper-temporal NDVI analysis was also used to map paddy rice (Thi et al., 2012). However, the phenological variations or temporal profile information of paddy rice were not really used despite the usage of images from different stages.

[Table 2]

\subsection{Category Three: VI or RADAR backscatter-based temporal analysis approaches}

Although multi-temporal images had been used in the algorithms of Category Two, the key phenological characteristics or variations in greenness/water content/soil based on time series analysis were not quantified and used for paddy rice mapping. The studies involved in Category Three used time series analysis for paddy rice mapping. Generally two kinds of algorithms were used: (1) According to the temporal variation of vegetation indices, paddy rice can be discriminated from other land covers by using the threshold-based approach (or decision tree) 
(Chen et al., 2011b; Oguro et al., 2001). For example, Chen et al. (2011b) used temporal NDVI data from 30-m HJ-1 A/B images for paddy rice mapping in southern China by using the threshold-based approach from temporal profile analysis. Li et al. (2012b) used the Landsatderived NDVI temporal profile analysis to map the cropping intensity change from 2004 to 2010 in Poyang Lake Region, China. Son et al. (2013) used EVI data and a threshold-based approach to map paddy rice in the Mekong Delta, Vietnam. In addition to optical data, cloud-free RADAR data was used for paddy rice mapping; for example, Nelson et al. (2014) used SAR X-band HH polarization data and successfully mapped paddy rice for 13 diverse footprints in South and Southeast Asia. Bouvet and Le Toan (2011) and Chen (2007) detected paddy rice through the increase of the co-polarized backscatter intensity between the transplanting phase and vegetative stage phase. One study also found the combined use of multi-temporal NDVI (EVI) data with SAR (Synthetic Aperture Radar) data to perform better than single application of either VIs or SAR (Oguro et al., 2001). In some studies thresholds were determined based on the temporal profile analysis with a semi-quantitative approach or expert knowledge, while others used a more quantitative approach by calculating the mean and standard deviation of variance data (Nuarsa et al., 2012). These methods tend to exclude and mask different land cover types one by one according to signature analysis of land cover before creating an automatic classifier, which can substantially improve classification efficiency and usually lead to higher accuracy than traditional classifiers (e.g., MLC). (2) The second subgroup of methods used time series analysis, such as spectral matching techniques (Thenkabail et al., 2009; Thenkaball et al., 2007) and the Linear Mixture Model (LMM) (Chen et al., 2011a). For example, a suite of methods including spectral matching techniques, decision trees, and ideal temporal profile data banks help to rapidly identify and classify rice areas over large spatial expanses by using time series NDVI 
datasets (Gumma et al., 2011; Gumma et al., 2014); those approaches are suitable for cloudy regions with complex landscapes. Chen et al. (2011a) used the LMM approach and Empirical Mode Decomposition (EMD) filtered NDVI data for rice classification and acquired promising results.

In sum, multi-temporal VI analysis was used to distinguish paddy rice from other land cover types in this category (Table 3). The hypothesis proposed in these studies is that the phenological patterns of paddy rice distinguishes from other vegetation, usually it has more water abundant phenomena in the beginning transplanting phase, is greener during the peak growing season (tillering phase), and has higher soil content in the harvest phase. The threshold-based approach can examine these variations of paddy rice; however, this approach is difficult to apply extensively due to the substantially diverse paddy rice cropping systems in different regions (Figure 4). For example, VI temporal profiles often exhibit considerable intra-class variability due to different climates and management practices in different regions (Wardlow et al., 2007). The second type of algorithms, despite its more quantitative mathematical mechanism, may be difficult to be extended to other regions with shifted cropping patterns. The intra-class variability of temporal profiles could introduce misclassification to the spectral matching methods (Lunetta et al., 2010). Therefore, a more robust rice identification needs a more clear quantitative expression and justification of certain physical characteristics and/or key phenological phases.

[Table 3]

\subsection{Category Four: phenology-based approaches through remote sensing recognition of key growth phases}

All three previous categories of studies have recognized the importance of the key paddy rice growth phase in paddy rice mapping; Category Three approaches added on the temporal 
variation of vegetation indices. However, quantitative recognition of the key phenological phases, e.g., transplanting, tillering, and harvest, were not examined using a remote sensing approach. In recent studies, more and more researchers have begun to use a more straightforward phenology-based approach for paddy rice mapping. For example, Xiao et al. (2002) found that the flooding and transplanting signals can be extracted by using the relationship between NDVI (EVI) and LSWI, specifically that LSWI values are temporarily greater than NDVI or EVI values during these phases. The relationship of these two VIs are more robust than the threshold approach based on individual VIs. Based on this unique remote sensing signal in the early period of the growing season and the masking of non-cropland layers, paddy rice can be extracted. This simple phenology-based approach is robust as paddy rice is the one crop that requires transplanting and an inundation environment. Based on this approach, continental scale paddy rice maps was generated, covering southern China, South Asia, and Southeast Asia by using 8day time series MODIS data (Xiao et al., 2006; Xiao et al., 2005). This method has attracted increasing attention and is now widely used in various geographical regions (Dong et al., 2015; Dong et al., 2016a; Dong et al., 2016b; Qin et al., 2015; Shi et al., 2013a; Zhang et al., 2015).

To date, several general improvements have been made. First, cloud disturbances in paddy rice planting areas create noises in the time series data that severely affects the phenological signal identification. Some efforts have been made to gap-fill the VI datasets in more sophisticated ways. For example, Sakamoto et al. (2007) improved the flood detecting approach by utilizing wavelet-based VI filtering and used the new VI products to detect temporal changes in the extent of annual flooding, and finally mapped inland aquaculture and triple rice-cropping areas in the Mekong Delta. 
Second, the flooding signals could be not only from transplanting of paddy rice, but also from flooding due to extreme rainfall events in summer, or the snow melt flooding in spring, therefore, the temporal window identification of transplanting is essential. Several studies have attempted to improve the phenology-based rice mapping method (Xiao et al., 2005) by defining the flooding and transplanting periods based on observed phenology data from agricultural meteorological stations (Peng, 2009; Peng et al., 2011; Shi et al., 2013b). The dependence of these improved methods on agricultural phenology data limited the approach's extensive applications in the regions without observations. Calendar data from scattered agricultural meteorological stations will also create large uncertainties when interpolated to regional or national scales. Some recent studies tried to use air temperature or land surface temperature (Dong et al., 2015; Zhang et al., 2015) to define the temporal window. For example, MODIS LST data was used to define the time window and provided more spatially explicit information by using the start dates of the thermal growing season in high latitude regions (Zhang et al., 2015), i.e., the starting point defined by a minimum LST higher than $5^{\circ} \mathrm{C}$. Air temperature was also used to define the starting point of the paddy rice transplanting phase (Dong et al., 2015). However, this method could only be suitable for temperate zones where cropping is limited by thermal conditions; in tropical zones, thermal conditions are not a constraining factor for paddy rice planting.

Third, the masking approaches of non-paddy rice classes, e.g., wetlands, have been improved. As paddy rice is not the only land cover type with flooding signals, the exclusion of non-paddy rice types is critical for reducing the commission errors of resultant paddy rice map. Water bodies, built-up land, and forests are relatively easy to eliminate; however, some land cover types like natural wetlands could have temporal profiles similar to that of rice. Shi et al. 
(2013a) discriminated wetland according to its longer growing season by using high NDVI values over 15 eight-day composites during one year.

Fourth, besides the optical RS-based VI relationship approach (Xiao et al., 2002), SAR datasets have also been used to detect flooding and transplanting signals of paddy rice fields. Torbick et al. (2011) used PALSAR FBS data and a decision tree approach to identify flooding signals that were compared and shown to be consistent with the MODIS LSWI/EVI based results. Other data sources have also been used to detect the transplanting of paddy rice; for example, the SSM/I brightness temperature-based Soil Wetness Index (SWI) was used to detect transplanting signals (Gupta et al., 2011), and the resultant estimated rice transplanting periods showed a good agreement (90\%) with the ground truth observations. The application of these new data sources is helpful for future operational paddy rice mapping.

[Table 4]

In addition to the transplanting-based paddy rice approach, an indicator considering both LSWI and EVI changes from tillering to heading phases was also used to map paddy rice (Qiu et al., 2015). Specifically, the variation of LSWI in paddy rice fields was found to be relatively smaller than that of other crops from tillering to heading dates. Thus, the ratios of LSWI change amplitude to 2-band Enhanced Vegetation Index (EVI2) during that period were utilized to generate an indicator, so-called the Combined Consideration of Vegetation phenology and Surface water variations (CCVS), for paddy rice mapping. This approach proved more robust in terms of intra-class rice variability when compared to the transplanting phenology-based approach (Xiao et al., 2006; Xiao et al., 2005). However, more validations in other regions could be needed for extensive applications of this algorithm. 


\section{Discussion}

\subsection{Major characteristics of evolution of paddy rice mapping methods}

Paddy rice mapping is an important topic due to its significance for human wellbeing and environmental issues. Beyond original research articles, two reviews have also been published: Kuenzer (2013) has summarized the different studies from the perspective of data types (high- to medium-resolution optical data, low-resolution optical data, hyperspectral data, and radar data); while Mosleh et al. (2015) reviewed the progress in rice area mapping and production forecasting, also taking the perspective of remote sensing data (optical and microwave imagery). This study tried to investigate the evolution of paddy rice mapping methods by summarizing the four categories of paddy rice mapping approaches. This trace analysis is helpful for the establishment of future operational paddy rice mapping capabilities. The major findings on the method of evolution can be summarized by the following:

In term of algorithms, the improvement of paddy rice mapping approaches is consistent with general land cover classification development. Specifically, it underwent traditional classifiers (classic supervised or unsupervised classifiers such as MLC) and visual interpretation, more intelligent classifiers (e.g., NN, SVM, and DTs), time series analysis-based or integrated approaches (e.g., spectral matching), and the simple and phenology-based approach through remote sensing recognition of key phenology signals. The mapping strategy changed from general land cover classification (universal land cover classifiers for general land cover types) to the more specific thematic mapping (specific for paddy rice). Due to the spectral variability in different periods and regions, the image statistic-based approaches in early stages had limits on the extension of classifier rules as all of these methods were region- and phase-dependent. As an alternative, time series data and phenology-based algorithms have been increasingly used for 
paddy rice as well as other crop mapping (Lobell and Asner, 2004; Pan et al., 2012; Wardlow and Egbert, 2008; Wardlow et al., 2007; Zhong et al., 2014).

In term of data sources, Landsat and AVHRR were almost the only optical data sources for paddy rice mapping before 2000. Landsat's applications in paddy rice mapping have the longest history (Fang et al., 1998; Mccloy et al., 1987; Oguro et al., 2003; Panigrahy and Parihar, 1992). Besides abundant local and small scale studies, national scale studies have also been conducted after 2000; for example, a paddy rice map was included in China's NLCD products, which includes six major categories and 25 subcategories derived from a visual interpretation approach based on Landsat imagery from multiple epochs: late 1980s, ca. 1995, ca. 2000, ca. 2005, and ca. 2010 (Liu et al., 2005; Liu et al., 2010; Zhang et al., 2014). Based on Landsat data, the National Agricultural Statistics Service (NASS) of the USA has also produced the Cropland Data Layer (CDL), which is a crop-specific classification product including paddy rice (Johnson and Mueller, 2010). The operation of the MODIS sensor greatly promoted paddy rice mapping efforts given its hypertemporal resolution, as well as the other sensors like SPOT-VGT, AVHRR, and MERIS. The free release of Landsat archive data by USGS/EROS provides an unprecedented data source for paddy rice mapping given its ideal spatial resolution and long records dating back to the 1970s. Synthetic Aperture Radar (SAR) is anticipated to play an important role in paddy rice mapping in tropical and subtropical regions given their frequent cloud coverage (Shao et al., 2001) and one study showed its even more promising capability in mapping rice area and transplanting dates (Asilo et al., 2014); however, its acquisition capability is still not as good as optical sensors.

In terms of input variables, optical remote sensing-based methods experienced an evolution from reflectance data, to NDVI/EVI, then to NDVI/EVI and LSWI/NDWI, and finally other combined indicators (e.g., CCVS, Qiu et al, 2015). Paddy rice fields are a dynamic mixture of 
soil, water, and green vegetation following specific growth phases. NDVI and EVI reflect the greenness while LSWI and NDWI yield flooding signatures. Xiao et al. (2002) proposed a quantitative method to define flooding (i.e., LSWI+ $\alpha>$ NDVI/EVI), Shi et al. (2013a) used NDWI to replace LSWI. The difference between LSWI and NDWI is in the usage of different shortwave infrared bands (using MODIS as an example, NDWI uses band 7 (2105 - $2155 \mathrm{~mm}$ ) while LSWI uses band $6(1628-1652 \mathrm{~mm})$. Another study also found that NDWI usage lead to a negligible increase in commission errors over studies that use LSWI, but that NDWI was also more sensitive to the presence of water in mixed land cover conditions typical of moderate spatial resolution analyses (Boschetti et al., 2014) which was consistent with (Shi et al., 2013a). Besides these existing VIs, one study also proposed a Rice Growth Vegetation Index (RGVI) and found it to have a good relationship with rice age and can be used for rice plant mapping (Nuarsa et al., 2011).

In terms of study hotspots, the study numbers are consistent with paddy rice production areas. Specifically, most studies focused on Southeast Asia and South Asia. Paddy rice mapping in tropical regions is more difficult due to the shorter growing season and more frequent cloud coverage. However, the phenology-based approach also encountered new challenges in cold temperate zones where the winter season is long, snowmelt occurs in spring, and precisely identifying the time period of the flooding and transplanting phases is vital (Zhang et al., 2015; Dong et al., 2016a, 2016b).

\subsection{Challenges and opportunities: implications for future paddy rice mapping}

Based on the literature review, future regional to global paddy rice mapping efforts should reduce the existing uncertainties in algorithms, data, and validation processes and involve the 
emerging advanced sensors and methods, as well as new crowdsourcing based validation approaches. Here we discuss the existing challenges and opportunities from the three aspects.

\subsubsection{Uncertainties and solutions in algorithms}

Agricultural statistical methods have been used for paddy rice monitoring for a long time (e.g., FAOSTAT). However, it is time-consuming with uncertainties from subjective measures; also, it has limited information in spatial distribution. Remote sensing methods has played a dominant role in paddy rice mapping, which is the foci of this study.

While the transplanting recognition-based paddy rice mapping methodology has been used increasingly for large scale paddy rice mapping in recent studies (e.g., South Asia, Southeast Asia, China) (Sun et al., 2009; Xiao et al., 2006; Xiao et al., 2005; Zhang et al., 2015), the intra-class variability of paddy rice fields continues to prevent the acquisition of accurate transplanting signals. One uncertainty in the algorithm is the setting of $\alpha$ (LSWI $+\alpha>$ EVI/NDVI); the original study set $\alpha$ as 0.05 (Xiao et al., 2005) while following studies used values ranging from 0 to 0.2 (Peng et al., 2011; Sun et al., 2009). For multiple cropping, setting $\alpha$ to 0.05 for early rice is promising. The reason for the uncertainty is the mixed pixel issue occurring between two rice croppings. The uncertainty could be reduced by using finer spatial resolution images (e.g., Landsat). The algorithm can however, work well in large field areas when using MODIS data (Zhang et al., 2015) and small field areas when using Landsat data (Dong et al., 2015; Qin et al., 2015). Qiu et al (2015) presented another indicator, the ratio of change amplitude of LSWI to EVI, that also proved robust. However, more assessments are necessary before its extensive application. Also, the predefined time window for transplanting could effectively improve classification accuracy, this would rely on either climate variable-based phenological definition (Zhang et al., 2015) or cropping intensity and rice planting calendar retrieval from time series vegetation indices data. 


\subsubsection{Uncertainties and solutions in data}

Given the dependence of paddy rice algorithms on temporal data, data availability is the major concern for operational paddy rice mapping, which is affected by clouds, fragmentation, cropping systems, etc. Although time series data is increasingly applied to paddy rice mapping, cloudinduced noises (bad observations due to clouds and shadows) are still the major limiting factor as paddy rice production regions are usually cloud-prone areas. Among existing satellite datasets, hyper-temporal MODIS data is an important source for rice mapping. Motohka et al. (2009) found that more than $65 \%$ MODIS observations from Terra satellite were contaminated with clouds in the case region of monsoon Asia. However, the combined use of MODIS data from both Terra and Aqua satellites decreased the rate of cloud contamination in the daily data to $43 \%$. Even with its daily revisit frequency, MODIS still has difficulty to provide sufficient numbers of good-quality observations for annual paddy rice mapping in moist tropical areas. Figure 5 showed the spatial pattern of bad observations (including clouds, cloud shadows) in monsoon Asia by using 8-day composite MODIS data. SAR imagery is a promising data source for paddy rice mapping given its cloud-free advantage (Bouvet and Le Toan, 2011; Nelson et al., 2014); however, it also has some limitations compared to optical remote sensing such as low data acquisition, relatively low temporal resolution, and speckle noises. The shorter growing season in multiple cropping systems is another issue for paddy rice mapping in tropical regions. In addition, fragmentation of paddy rice fields is another challenge. While $90 \%$ of global paddy rice fields are distributed in Asia, most cropland fields are patchy and fragmented. The widely-used MODIS data have a 500-m resolution that cannot overcome the intra-class temporal variability of paddy rice. 


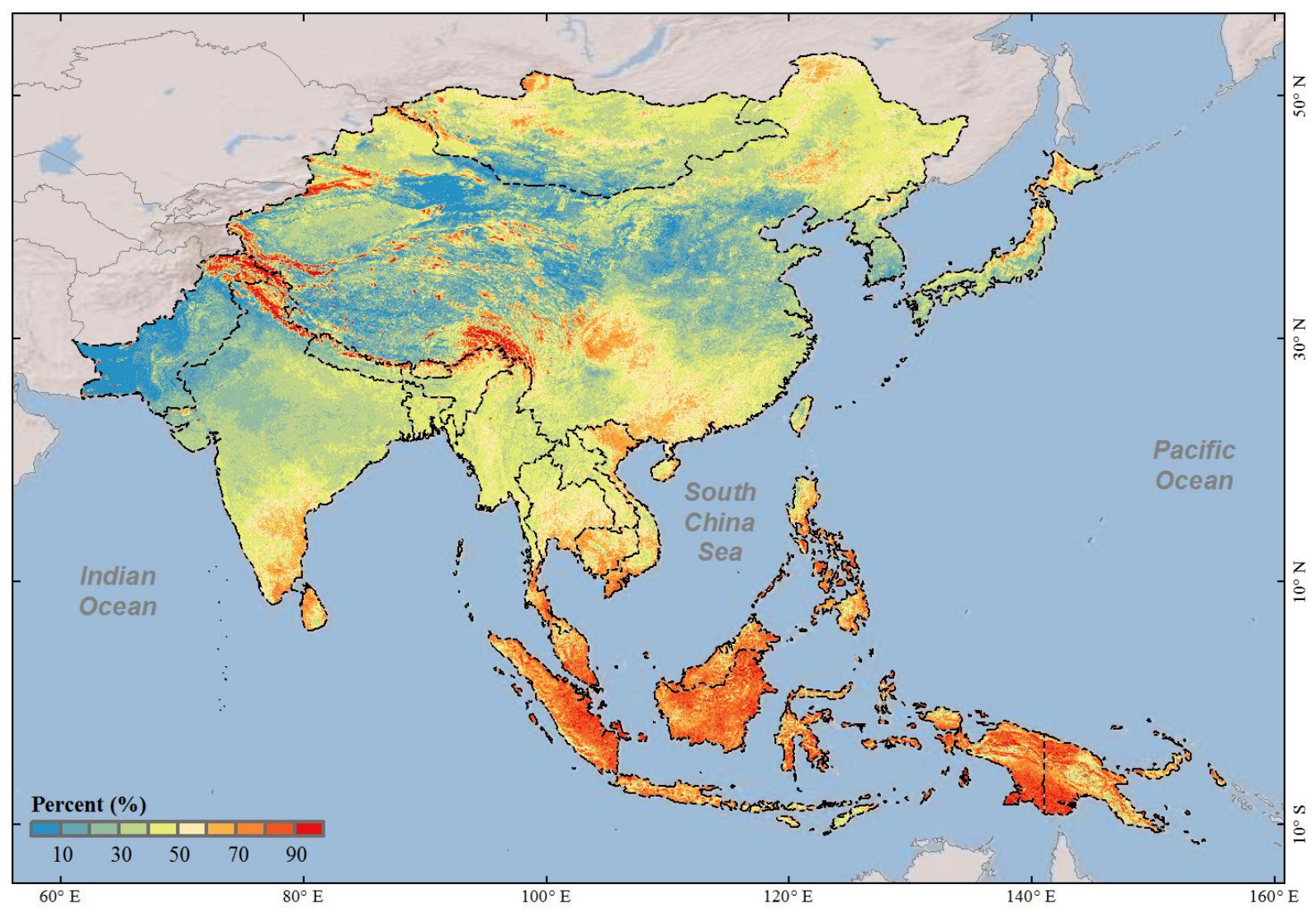

Figure 5. Spatial distribution of the bad observation frequency in monsoon Asia in 2010 by using 8-day MODIS data (MOD09A1). The bad observations were defined referring to the quality layer and the blue band (Xiao et al., 2005).

Despite these challenges, many opportunities continue to arise, especially from increasing data availability and resolutions, improved algorithms, and increasing ground truth data. First, increasing data sources and improved data resolution facilitate improved spatially explicit paddy rice maps. The generation of time series Landsat reflectance data (e.g., WELD) (Roy et al., 2010) will facilitate the expansion of paddy rice mapping to broader spatial (30-m) and temporal (back to the 1980s) extents. The new ESA Sentinel-2A/B sensors together with Landsat 8 data offer unprecedented opportunities at $\sim 30$-m spatial resolution and $<5$ day temporal resolution (Wulder et al., 2011) datasets highly useful for mapping and tracking the dynamics of rice paddies, 
especially in tropical countries. A recent study showed the feasibility of annual paddy rice mapping in a single cropping area, temperate zone of Asia by using Landsat 8 data (Dong et al., 2016a). Second, the algorithms have been evolved to make the most of the improved data mentioned in the Section 4.1.

\subsubsection{Calibration/Validation data and other ancillary information}

Calibration/Validation (Cal/Val) is a critical component for land cover mapping studies. Existing $\mathrm{Cal} / \mathrm{Val}$ data collection methods include utility of higher resolution images and ground surveys. Citizen science plays an increasing important role in the collection of Cal/Val data (Xiao et al., 2011). The Global Geo-Referenced Field Photo Library (http://www.eomf.ou.edu/photos/) supports this growing collaboration between citizens and scientists, storing more than 150,000 photos from the fields as of Feb. 1, 2016. Google Earth (GE) is also a source of high resolution image collections, and GE-based region of interest (ROI) online tools or packages, e.g., GeoWiki (Fritz et al., 2009) and GM (Gong et al., 2013), enable ROI extraction by using GE imagery.

Priori knowledge and ancillary data are also useful for avoiding commission errors. For example, DEM data were used to reduce the influence of elevation and slope on the estimation of paddy rice (Peng et al., 2011; Xiao et al., 2006); and the ALOS/PALSAR-based forest map was also used as a mask to reduce the commission errors (Dong et al., 2016a).

\section{Conclusions}

Paddy rice mapping is not a new topic for remote sensing application. However, to date there have been no available global paddy rice maps to support such studies as greenhouse gas emission, water use, food security, disease control, and climate change. To motivate the production of robust large-scale paddy rice maps, this study reviewed previous efforts in paddy rice mapping. In particular, we tracked the evolution of paddy rice mapping methods and tried to explore an operational framework for universal, reliable paddy rice mapping. 
The critical role played by phenological signals in key crop phases has been recognized since the 1980s in the agricultural remote sensing field; the field next grew into using temporal profile analysis of key growth stages to identify rice; later on, remote sensing identification of transplanting has been increasingly used for paddy rice mapping. The temporal analysis and phenology-based approaches was considered promising methods for thematic paddy rice mapping. Existing phenology-based studies successfully mapped yearly paddy rice on national or subcontinental scales by using MODIS data, epoch-scale paddy rice on regional scale by using Landsat data.

However, the accuracies of these approaches have been largely limited by the availability of time series image data. The intra-class variability of paddy rice within variant cropping systems is also a big challenge for global paddy rice mapping, thus prior knowledge about cropping intensity and calendars via statistical analysis on sampling sites at a global level would be necessary. The time window of the transplanting phase and masking of other land cover types have proven important for generation of paddy rice maps. Thermal conditions can help define the time window of paddy rice transplantation in temperature zones and simplify mapping process. However, a universal mapping strategy will need to acquire cropping intensity and calendar information by using sampling-based information. The mixed pixel issues can be solved to a great degree by using higher resolution (e.g., Landsat-like) datasets. SAR data can be used as complementary data for paddy rice mapping.

Since 1987 to the present, remote sensing observation capabilities have improved dramatically such that our paddy rice identification and mapping abilities have been substantially improved. The successful production of a global paddy rice map relies on improved data acquisition capability (e.g., future sharing of the combined Landsat and Centinel-2 data), improved algorithms 
(e.g., the application of phenology and object-based approaches), as well as improved computing capacity (e.g., Google Earth Engine and Amazon Cloud Drive). After a successful implementation of global paddy rice mapping, our estimations about magnitudes and spatial variations in $\mathrm{CH}_{4}$ emission, water use, and food production will be greatly improved. In addition, the spatially explicit rice maps would contribute to more precise epidemiological models. The rice dynamic information would help us to better understand response and adaption of agricultural system to global climate change.

\section{Acknowledgements}

This study was supported by the NASA Land Use and Land Cover Change program (NNX11AJ35G, NNX14AD78G), the US National Science Foundation EPSCoR program (IIA1301789), and the National Institutes of Health (1R01AI101028-01-A2). We thank three anonymous reviewers from this journal, and Geli Zhang, Yuanwei Qin, Yuting Zhou, and Jie Wang at the University of Oklahoma for their comments in the earlier versions of manuscripts. We also thank Sarah Xiao at Yale University for English editing of the manuscript. 


\section{References}

Arafat, S.M., Aboelghar, M.A., Ahmed, E.F., 2013. Crop Discrimination Using Field Hyper Spectral Remotely Sensed Data.

Asilo, S., de Bie, K., Skidmore, A., Nelson, A., Barbieri, M., Maunahan, A., 2014. Complementarity of Two Rice Mapping Approaches: Characterizing Strata Mapped by Hypertemporal MODIS and Rice Paddy Identification Using Multitemporal SAR. Remote Sensing 6, 12789-12814.

Bontemps, S., Defourny, P., Eric Van Bogaert, Arino, O., Kalogirou, V., Perez, J.R., 2011. GLOBCOVER 2009: Products Description and Validation Report

Boschetti, M., Nutini, F., Manfron, G., Brivio, P.A., Nelson, A., 2014. Comparative Analysis of Normalised Difference Spectral Indices Derived from MODIS for Detecting Surface Water in Flooded Rice Cropping Systems. Plos One 9.

Bouman, B., 2009. How much water does rice use. Rice Today 8, 28-29.

Bouvet, A., Le Toan, T., 2011. Use of ENVISAT/ASAR wide-swath data for timely rice fields mapping in the Mekong River Delta. Remote Sens Environ 115, 1090-1101.

Bridhikitti, A., Overcamp, T.J., 2012. Estimation of Southeast Asian rice paddy areas with different ecosystems from moderate-resolution satellite imagery. Agric. Ecosyst. Environ. 146, 113-120.

Brouwer, C., Prins, K., Heibloem, M., 1989. Irrigation water management: Irrigation scheduling. Training manual.

Chang, K.W., Shen, Y., Lo, J.C., 2005. Predicting rice yield using canopy reflectance measured at booting stage. Agron. J. 97, 872-878.

Chen, C., McNairn, H., 2006. A neural network integrated approach for rice crop monitoring. Int J Remote Sens 27, 1367-1393.

Chen, C.F., Son, N.T., Chang, L.Y., Chen, C.R., 2011a. Classification of rice cropping systems by empirical mode decomposition and linear mixture model for time-series MODIS 250 m NDVI data in the Mekong Delta, Vietnam. Int J Remote Sens 32, 5115-5134.

Chen, J., Chen, J., Liao, A.P., Cao, X., Chen, L.J., Chen, X.H., He, C.Y., Han, G., Peng, S., Lu, M., Zhang, W.W., Tong, X.H., Mills, J., 2015. Global land cover mapping at $30 \mathrm{~m}$ resolution: A POK-based operational approach. Isprs J Photogramm 103, 7-27.

Chen, J.S., Huang, J.X., Hu, J.X., 2011b. Mapping rice planting areas in southern China using the China Environment Satellite data. Math Comput Model 54, 1037-1043.

Chen, J.S., Lin, H., Pei, Z.Y., 2007. Application of ENVISAT ASAR data in mapping rice crop growth in southern china. Ieee Geosci Remote $S$ 4, 431-435.

Cheng, Q., 2006. Multisensor comparisons for validation of MODIS vegetation indices. Pedosphere 16, 362-370.

Dong, J., Xiao, X., Kou, W., Qin, Y., Zhang, G., Li, L., Jin, C., Zhou, Y., Wang, J., Biradar, C., Liu, J., Moore Iii, B., 2015. Tracking the dynamics of paddy rice planting area in 19862010 through time series Landsat images and phenology-based algorithms. Remote Sens Environ 162, 154-168.

Dong, J., Xiao, X., Menarguez, M.A., Zhang, G., Qin, Y., Thau, D., Biradar, C., Moore, B., 2016a. Mapping paddy rice planting area in northeastern Asia with Landsat 8 images, phenology-based algorithm and Google Earth Engine. Remote Sens. Environ. 
Dong, J., Xiao, X., Zhang, G., Menarguez, M.A., Choi, C.Y., Qin, Y., Luo, P., Zhang, Y., Moore, B., 2016b. Northward expansion of paddy rice in northeastern Asia during 20002014. Geophys Res Lett 43, 3754-3761.

Ehhalt, D., Prather, M., Dentener, F., Derwent, R., Dlugokencky, E.J., Holland, E., Isaksen, I., Katima, J., Kirchhoff, V., Matson, P., 2001. Atmospheric chemistry and greenhouse gases. Pacific Northwest National Laboratory (PNNL), Richland, WA (US).

Elert, E., 2014. Rice by the numbers: A good grain. Nature 514, S50-S51.

Fang, H.L., 1998. Rice crop area estimation of an administrative division in China using remote sensing data. Int J Remote Sens 19, 3411-3419.

Fang, H.L., Wu, B.F., Liu, H.Y., Huang, X., 1998. Using NOAA AVHRR and landsat TM to estimate rice area year-by-year. Int J Remote Sens 19, 521-525.

FAOSTAT, 2010. Statistical Database of the Food and Agricultural Organization of the United Nations.

Feng, R., Zhang, Y.-s., Qian, Y.-1., Yu, W.-y., Ji, R.-p., Wu, J.-w., Chen, P.-s., 2011. Extraction of single cropping rice area in Northeast China based on multi-temporal MODIS data. Shengtaixue Zazhi 30, 2570-2576.

Friedl, M.A., McIver, D.K., Hodges, J.C.F., Zhang, X.Y., Muchoney, D., Strahler, A.H., Woodcock, C.E., Gopal, S., Schneider, A., Cooper, A., Baccini, A., Gao, F., Schaaf, C., 2002. Global land cover mapping from MODIS: algorithms and early results. Remote Sens Environ 83, 287-302.

Fritz, S., McCallum, I., Schill, C., Perger, C., Grillmayer, R., Achard, F., Kraxner, F., Obersteiner, M., 2009. Geo-Wiki.Org: The Use of Crowdsourcing to Improve Global Land Cover. Remote Sensing 1, 345-354.

Fritz, S., See, L., McCallum, I., You, L., Bun, A., Moltchanova, E., Duerauer, M., Albrecht, F., Schill, C., Perger, C., Havlik, P., Mosnier, A., Thornton, P., Wood-Sichra, U., Herrero, M., Becker-Reshef, I., Justice, C., Hansen, M., Gong, P., Abdel Aziz, S., Cipriani, A., Cumani, R., Cecchi, G., Conchedda, G., Ferreira, S., Gomez, A., Haffani, M., Kayitakire, F., Malanding, J., Mueller, R., Newby, T., Nonguierma, A., Olusegun, A., Ortner, S., Rajak, D.R., Rocha, J., Schepaschenko, D., Schepaschenko, M., Terekhov, A., Tiangwa, A., Vancutsem, C., Vintrou, E., Wenbin, W., van der Velde, M., Dunwoody, A., Kraxner, F., Obersteiner, M., 2015. Mapping global cropland and field size. Glob Chang Biol 21, 1980-1992.

Frolking, S., Qiu, J.J., Boles, S., Xiao, X.M., Liu, J.Y., Zhuang, Y.H., Li, C.S., Qin, X.G., 2002. Combining remote sensing and ground census data to develop new maps of the distribution of rice agriculture in China. Global Biogeochem Cy 16.

Gao, B.C., 1996. NDWI - A normalized difference water index for remote sensing of vegetation liquid water from space. Remote Sens Environ 58, 257-266.

Gilbert, M., Golding, N., Zhou, H., Wint, G.R., Robinson, T.P., Tatem, A.J., Lai, S., Zhou, S., Jiang, H., Guo, D., Huang, Z., Messina, J.P., Xiao, X., Linard, C., Van Boeckel, T.P., Martin, V., Bhatt, S., Gething, P.W., Farrar, J.J., Hay, S.I., Yu, H., 2014. Predicting the risk of avian influenza A H7N9 infection in live-poultry markets across Asia. Nat Commun 5, 4116.

Gilbert, M., Xiao, X.M., Pfeiffer, D.U., Epprecht, M., Boles, S., Czarnecki, C., Chaitaweesub, P., Kalpravidh, W., Minh, P.Q., Otte, M.J., Martin, V., Slingenbergh, J., 2008. Mapping H5N1 highly pathogenic avian influenza risk in Southeast Asia. P Natl Acad Sci USA 105, 4769-4774. 
Gong, P., Wang, J., Yu, L., Zhao, Y., Zhao, Y., Liang, L., Niu, Z., Huang, X., Fu, H., Liu, S., Li, C., Li, X., Fu, W., Liu, C., Xu, Y., Wang, X., Cheng, Q., Hu, L., Yao, W., Zhang, H., Zhu, P., Zhao, Z., Zhang, H., Zheng, Y., Ji, L., Zhang, Y., Chen, H., Yan, A., Guo, J., Yu, L., Wang, L., Liu, X., Shi, T., Zhu, M., Chen, Y., Yang, G., Tang, P., Xu, B., Giri, C., Clinton, N., Zhu, Z., Chen, J., Chen, J., 2013. Finer resolution observation and monitoring of global land cover: first mapping results with Landsat TM and ETM+ data. Int J Remote Sens 34, 2607-2654.

Gumma, M.K., Nelson, A., Thenkabail, P.S., Singh, A.N., 2011. Mapping rice areas of South Asia using MODIS multitemporal data. J Appl Remote Sens 5, 053547.

Gumma, M.K., Thenkabail, P.S., Maunahan, A., Islam, S., Nelson, A., 2014. Mapping seasonal rice cropland extent and area in the high cropping intensity environment of Bangladesh using MODIS $500 \mathrm{~m}$ data for the year 2010. Isprs J Photogramm 91, 98-113.

Gupta, P.K., Oza, S.R., Panigrahy, S., 2011. Monitoring transplanting operation of rice crop using passive microwave radiometer data. Biosyst Eng 108, 28-35.

Huete, A., Didan, K., Miura, T., Rodriguez, E.P., Gao, X., Ferreira, L.G., 2002. Overview of the radiometric and biophysical performance of the MODIS vegetation indices. Remote Sens Environ 83, 195-213.

Huke, R.E., Huke, E.H., Institute, I.R.R., 1997. Rice area by type of culture : South, Southeast and East Asia ; a revised and updated data base. Manila : IRRI.

Inoue, Y., Kurosu, T., Maeno, H., Uratsuka, S., Kozu, T., Dabrowska-Zielinska, K., Qi, J., 2002. Season-long daily measurements of multifrequency (Ka, $\mathrm{Ku}, \mathrm{X}, \mathrm{C}$, and $\mathrm{L}$ ) and fullpolarization backscatter signatures over paddy rice field and their relationship with biological variables. Remote Sens Environ 81, 194-204.

Inoue, Y., Sakaiya, E., 2013. Relationship between X-band backscattering coefficients from high-resolution satellite SAR and biophysical variables in paddy rice. Remote Sens Lett 4, 288-295.

Inoue, Y., Sakaiya, E., Wang, C.Z., 2014. Capability of C-band backscattering coefficients from high-resolution satellite SAR sensors to assess biophysical variables in paddy rice. Remote Sens Environ 140, 257-266.

Jain, M., Mondal, P., DeFries, R.S., Small, C., Galford, G.L., 2013. Mapping cropping intensity of smallholder farms: A comparison of methods using multiple sensors. Remote Sens Environ 134, 210-223.

Jeong, S., Kang, S., Jang, K., Lee, H., Hong, S., Ko, D., 2012. Development of Variable Threshold Models for detection of irrigated paddy rice fields and irrigation timing in heterogeneous land cover. Agr Water Manage 115, 83-91.

Johnson, D.M., Mueller, R., 2010. The 2009 Cropland Data Layer. Photogramm Eng Rem S 76, 1201-1205.

Kamthonkiat, D., Honda, K., Turral, H., Tripathi, N.K., Wuwongse, V., 2005. Discrimination of irrigated and rainfed rice in a tropical agricultural system using SPOT VEGETATION NDVI and rainfall data. Int J Remote Sens 26, 2527-2547.

Kim, H.O., Yeom, J.M., 2012. Multi-Temporal Spectral Analysis of Rice Fields in South Korea Using MODIS and RapidEye Satellite Imagery. Journal of Astronomy and Space Sciences 29, 407-411.

Kim, H.O., Yeom, J.M., 2014. Effect of red-edge and texture features for object-based paddy rice crop classification using RapidEye multi-spectral satellite image data. Int J Remote Sens 35, 7046-7068. 
Kirches, G., Brockmann, C., Boettcher, M., Peters, M., Bontemps, S., Lamarche, C., Schlerf, M., Santoro, M., Defourny, P., 2014. Land Cover CCI Product User Guide: Version 2.

Kuenzer, C., Knauer, K., 2013. Remote sensing of rice crop areas. Int J Remote Sens 34, 2101 2139.

Kurosu, T., Fujita, M., Chiba, K., 1995. MONITORING OF RICE CROP GROWTH FROM SPACE USING THE ERS-1 C-BAND SAR. IEEE Trans Geosci Remote Sens 33, 1092 1096.

Kurosu, T., Fujita, M., Chiba, K., 1997. The identification of rice fields using multi-temporal ERS-1 C band SAR data. Int J Remote Sens 18, 2953-2965.

Le Toan, T., Ribbes, F., Li-Fang, W., Floury, N., Kung-Hau, D., Jin Au, K., Fujita, M., Kurosu, T., 1997. Rice crop mapping and monitoring using ERS-1 data based on experiment and modeling results. IEEE Trans Geosci Remote Sens 35, 41-56.

Leff, B., Ramankutty, N., Foley, J.A., 2004. Geographic distribution of major crops across the world. Global Biogeochem Cy 18, n/a-n/a.

Li, K., Brisco, B., Yun, S., Touzi, R., 2012a. Polarimetric decomposition with RADARSAT-2 for rice mapping and monitoring. Canadian Journal of Remote Sensing 38, 169-179.

Li, L., Dong, J., Njeudeng Tenku, S., Xiao, X., 2015. Mapping Oil Palm Plantations in Cameroon Using PALSAR 50-m Orthorectified Mosaic Images. Remote Sensing 7, 1206-1224.

Li, P., Feng, Z.M., Jiang, L.G., Liu, Y.J., Xiao, X.M., 2012b. Changes in rice cropping systems in the Poyang Lake Region, China during 2004-2010. Journal of Geographical Sciences 22, 653-668.

Li, Q., Zhang, H., Du, X., Wen, N., Tao, Q., 2014. County-level rice area estimation in southern China using remote sensing data. J Appl Remote Sens 8.

Liu, J., Liu, M., Tian, H., Zhuang, D., Zhang, Z., Zhang, W., Tang, X., Deng, X., 2005. Spatial and temporal patterns of China's cropland during 1990-2000: An analysis based on Landsat TM data. Remote Sens Environ 98, 442-456.

Liu, J.Y., Zhang, Z.X., Xu, X.L., Kuang, W.H., Zhou, W.C., Zhang, S.W., Li, R.D., Yan, C.Z., Yu, D.S., Wu, S.X., Nan, J., 2010. Spatial patterns and driving forces of land use change in China during the early 21st century. Journal of Geographical Sciences 20, 483-494.

Lobell, D.B., Asner, G.P., 2004. Cropland distributions from temporal unmixing of MODIS data. Remote Sens Environ 93, 412-422.

Lunetta, R.S., Shao, Y., Ediriwickrema, J., Lyon, J.G., 2010. Monitoring agricultural cropping patterns across the Laurentian Great Lakes Basin using MODIS-NDVI data. International Journal of Applied Earth Observation and Geoinformation 12, 81-88.

Maclean, J.L., Hettel, G.P., 2002. Rice almanac: Source book for the most important economic activity on earth. IRRI (free PDF download).

Mccloy, K.R., Smith, F.R., Robinson, M.R., 1987. Monitoring Rice Areas Using Landsat Mss Data. Int J Remote Sens 8, 741-749.

Monfreda, C., Ramankutty, N., Foley, J.A., 2008. Farming the planet: 2. Geographic distribution of crop areas, yields, physiological types, and net primary production in the year 2000. Global Biogeochem Cy 22.

Mosleh, M.K., Hassan, Q.K., 2014. Development of a Remote Sensing-Based "Boro" Rice Mapping System. Remote Sensing 6, 1938-1953. 
Mosleh, M.K., Hassan, Q.K., Chowdhury, E.H., 2015. Application of Remote Sensors in Mapping Rice Area and Forecasting Its Production: A Review. Sensors (Basel) 15, 769791.

Motohka, T., Nasahara, K.N., Miyata, A., Mano, M., Tsuchida, S., 2009. Evaluation of optical satellite remote sensing for rice paddy phenology in monsoon Asia using a continuous in situ dataset. Int J Remote Sens 30, 4343-4357.

Nelson, A., Gumma, M.K., 2015. A map of lowland rice extent in the major rice growing countries of Asia.

Nelson, A., Setiyono, T., Rala, A.B., Quicho, E.D., Raviz, J.V., Abonete, P.J., Maunahan, A.A., Garcia, C.A., Bhatti, H.Z.M., Villano, L.S., Thongbai, P., Holecz, F., Barbieri, M., Collivignarelli, F., Gatti, L., Quilang, E.J.P., Mabalay, M.R.O., Mabalot, P.E., Barroga, M.I., Bacong, A.P., Detoito, N.T., Berja, G.B., Varquez, F., Wahyunto, Kuntjoro, D., Murdiyati, R., Pazhanivelan, S., Kannan, P., Mary, P.C.N., Subramanian, E., Rakwatin, P., Intrman, A., Setapayak, T., Lertna, S., Minh, V.Q., Tuan, V.Q., Duong, T.H., Quyen, N.H., Kham, D.V., Hin, S., Veasna, T., Yadav, M., Chin, C., Ninh, N.H., 2014. Towards an Operational SAR-Based Rice Monitoring System in Asia: Examples from 13

Demonstration Sites across Asia in the RIICE Project. Remote Sensing 6, 10773-10812.

Niel, T.G.V., McVicar, T.R., 2003. A simple method to improve field-level rice identification: toward operational monitoring with satellite remote sensing. Aust J Exp Agr 43, 379.

Nuarsa, I.W., Nishio, F., Hongo, C., 2011. Spectral characteristics and mapping of rice plants using multi-temporal Landsat data. J Agr Sci 3, p54.

Nuarsa, I.W., Nishio, F., Hongo, C., Mahardika, I.G., 2012. Using variance analysis of multitemporal MODIS images for rice field mapping in Bali Province, Indonesia. Int $\mathrm{J}$ Remote Sens 33, 5402-5417.

Oguro, Y., Suga, Y., Takeuchi, S., Ogawa, H., Tsuchiya, K., 2003. Monitoring of a rice field using Landsat-5 TM and Landsat-7 ETM+ data. Calibration, Characterization of Satellite Sensors, Physical Parameters Derived from Satellite Data 32, 2223-2228.

Oguro, Y., Suga, Y., Takeuchi, S., Ogawa, M., Konishi, T., Tsuchiya, K., 2001. Comparison of SAR and optical sensor data for monitoring of rice plant around Hiroshima, in: Tsuchiya, K. (Ed.), Calibration and Characterization of Satellite Sensors and Accuracy of Derived Physical Parameters, pp. 195-200.

Okamoto, K., Kawashima, H., 1999. Estimation of rice-planted area in the tropical zone using a combination of optical and microwave satellite sensor data. Int J Remote Sens 20, 10451048.

Pan, X.Z., Uchida, S., Liang, Y., Hirano, A., Sun, B., 2010. Discriminating different landuse types by using multitemporal NDXI in a rice planting area. Int J Remote Sens 31, 585596.

Pan, Y., Li, L., Zhang, J., Liang, S., Zhu, X., Sulla-Menashe, D., 2012. Winter wheat area estimation from MODIS-EVI time series data using the Crop Proportion Phenology Index. Remote Sens Environ 119, 232-242.

Panigrahy, S., Parihar, J.S., 1992. Role of Middle Infrared Bands of Landsat Thematic Mapper in Determining the Classification Accuracy of Rice. Int J Remote Sens 13, 2943-2949.

Peng, D., 2009. The study on the method of rice yield estimation using statistical and MODIS data. Zhejiang University, Hangzhou. 
Peng, D.L., Huete, A.R., Huang, J.F., Wang, F.M., Sun, H.S., 2011. Detection and estimation of mixed paddy rice cropping patterns with MODIS data. International Journal of Applied Earth Observation and Geoinformation 13, 13-23.

Qin, Y., Xiao, X., Dong, J., Zhou, Y., Zhu, Z., Zhang, G., Du, G., Jin, C., Kou, W., Wang, J., Li, X., 2015. Mapping paddy rice planting area in cold temperate climate region through analysis of time series Landsat 8 (OLI), Landsat 7 (ETM+) and MODIS imagery. Isprs J Photogramm 105, 220-233.

Qiu, B., Li, W., Tang, Z., Chen, C., Qi, W., 2015. Mapping paddy rice areas based on vegetation phenology and surface moisture conditions. Ecol Indic 56, 79-86.

Ramankutty, N., Evan, A.T., Monfreda, C., Foley, J.A., 2008. Farming the planet: 1. Geographic distribution of global agricultural lands in the year 2000. Global Biogeochem Cy 22.

Rao, P.P.N., Rao, V.R., 1987. Rice Crop Identification and Area Estimation Using RemotelySensed Data from Indian Cropping Patterns. Int J Remote Sens 8, 639-650.

Roy, D.P., Ju, J.C., Kline, K., Scaramuzza, P.L., Kovalskyy, V., Hansen, M., Loveland, T.R., Vermote, E., Zhang, C.S., 2010. Web-enabled Landsat Data (WELD): Landsat ETM plus composited mosaics of the conterminous United States. Remote Sens Environ 114, 35-49.

Sakamoto, T., Van Nguyen, N., Kotera, A., Ohno, H., Ishitsuka, N., Yokozawa, M., 2007. Detecting temporal changes in the extent of annual flooding within the Cambodia and the Vietnamese Mekong Delta from MODIS time-series imagery. Remote Sens Environ 109, 295-313.

Sakamoto, T., Van Phung, C., Kotera, A., Nguyen, K.D., Yokozawa, M., 2009. Analysis of rapid expansion of inland aquaculture and triple rice-cropping areas in a coastal area of the Vietnamese Mekong Delta using MODIS time-series imagery. Landscape Urban Plan 92, 34-46.

Sass, R.L., Cicerone, R.J., 2002. Photosynthate allocations in rice plants: Food production or atmospheric methane? P Natl Acad Sci USA 99, 11993-11995.

Sass, R.L., Fisher, F.M., Ding, A., Huang, Y., 1999. Exchange of methane from rice fields: National, regional, and global budgets. J Geophys Res-Atmos 104, 26943-26951.

Shao, Y., Fan, X.T., Liu, H., Xiao, J.H., Ross, S., Brisco, B., Brown, R., Staples, G., 2001. Rice monitoring and production estimation using multitemporal RADARSAT. Remote Sens Environ 76, 310-325.

Shi, J.-j., Huang, J.-f., Zhang, F., 2013a. Multi-year monitoring of paddy rice planting area in Northeast China using MODIS time series data. J Zhejiang Univ-Sc B 14, 934-946.

Shi, J.J., Huang, J.F., Zhang, F., 2013b. Multi-year monitoring of paddy rice planting area in Northeast China using MODIS time series data. J Zhejiang Univ-Sc B 14, 934-946.

Shiu, Y.-S., Lin, M.-L., Huang, C.-H., Chu, T.-H., 2012. Mapping paddy rice agriculture in a highly fragmented area using a geographic information system object-based post classification process. J Appl Remote Sens 6, 063526.

Son, N.-T., Chen, C.-F., Chen, C.-R., Duc, H.-N., Chang, L.-Y., 2013. A Phenology-Based Classification of Time-Series MODIS Data for Rice Crop Monitoring in Mekong Delta, Vietnam. Remote Sensing 6, 135-156.

Song, S.L., Gong, W., Zhu, B., Huang, X., 2011. Wavelength selection and spectral discrimination for paddy rice, with laboratory measurements of hyperspectral leaf reflectance. Isprs J Photogramm 66, 672-682.

Suga, Y., Konishi, T., 2008. Rice crop monitoring using X, C and L band SAR data, pp. 710410710410-710410. 
Sun, H.S., Huang, J.F., Huete, A.R., Peng, D.L., Zhang, F., 2009. Mapping paddy rice with multi-date moderate-resolution imaging spectroradiometer (MODIS) data in China. $\mathbf{J}$ Zhejiang Univ-Sc A 10, 1509-1522.

Tan, C.P., Koay, J.Y., Lim, K.S., Ewe, H.T., Chuah, H.T., 2007. Classification of multi-temporal SAR images for rice crops using combined Entropy Decomposition and Support Vector Machine technique. Progress in Electromagnetics Research-Pier 71, 19-39.

Tao, F., Hayashi, Y., Zhang, Z., Sakamoto, T., Yokozawa, M., 2008. Global warming, rice production, and water use in China: Developing a probabilistic assessment. Agric For Meteorol 148, 94-110.

Tennakoon, S.B., Murty, V.V.N., Eiumnoh, A., 1992. Estimation of Cropped Area and GrainYield of Rice Using Remote-Sensing Data. Int J Remote Sens 13, 427-439.

Thenkabail, P.S., Dheeravath, V., Biradar, C.M., Gangalakunta, O.R.P., Noojipady, P., Gurappa, C., Velpuri, M., Gumma, M., Li, Y., 2009. Irrigated Area Maps and Statistics of India Using Remote Sensing and National Statistics. Remote Sensing 1, 50-67.

Thenkaball, P.S., GangadharaRao, P., Biggs, T.W., Krishna, M., Turral, H., 2007. Spectral matching techniques to determine historical Land-use/Land-cover (LULC) and irrigated areas using time-series 0.1-degree AVHRR pathfinder datasets. Photogramm Eng Rem S 73, 1029-1040.

Thi, T.H.N., De Bie, C., Ali, A., Smaling, E.M.A., Chu, T.H., 2012. Mapping the irrigated rice cropping patterns of the Mekong delta, Vietnam, through hyper-temporal SPOT NDVI image analysis. Int J Remote Sens 33, 415-434.

Torbick, N., Salas, W.A., Hagen, S., Xiao, X.M., 2011. Monitoring Rice Agriculture in the Sacramento Valley, USA With Multitemporal PALSAR and MODIS Imagery. IEEE J Sel Top Appl Earth Obs 4, 451-457.

Tornos, L., Huesca, M., Dominguez, J.A., Moyano, M.C., Cicuendez, V., Recuero, L., PalaciosOrueta, A., 2015. Assessment of MODIS spectral indices for determining rice paddy agricultural practices and hydroperiod. Isprs J Photogramm 101, 110-124.

Turner, M.D., Congalton, R.G., 1998. Classification of multi-temporal SPOT-XS satellite data for mapping rice fields on a West African floodplain. Int J Remote Sens 19, 21-41.

van Groenigen, K.J., van Kessel, C., Hungate, B.A., 2013. Increased greenhouse-gas intensity of rice production under future atmospheric conditions. Nature Climate Change 3, 288-291.

Wang, C.Z., Wu, J.P., Zhang, Y., Pan, G.D., Qi, J.G., Salas, W.A., 2009. Characterizing L-Band Scattering of Paddy Rice in Southeast China With Radiative Transfer Model and Multitemporal ALOS/PALSAR Imagery. IEEE Trans Geosci Remote Sens 47, 988-998.

Wang, H., Chen, J., Wu, Z., Lin, H., 2011a. Rice heading date retrieval based on multi-temporal MODIS data and polynomial fitting. Int J Remote Sens, 1-12.

Wang, L.L., Song, C.C., Song, Y.Y., Guo, Y.D., Wang, X.W., Sun, X.X., 2010. Effects of reclamation of natural wetlands to a rice paddy on dissolved carbon dynamics in the Sanjiang Plain, Northeastern China. Ecol Eng 36, 1417-1423.

Wang, W., Yao, X., Tian, Y.C., Liu, X.J., Ni, J., Cao, W.X., Zhu, Y., 2012. Common Spectral Bands and Optimum Vegetation Indices for Monitoring Leaf Nitrogen Accumulation in Rice and Wheat. J Integr Agr 11, 2001-2012.

Wang, Z.M., Song, K.S., Ma, W.H., Ren, C.Y., Zhang, B., Liu, D.W., Chen, J.M., Song, C.C., 2011b. Loss and Fragmentation of Marshes in the Sanjiang Plain, Northeast China, 19542005. Wetlands 31, 945-954. 
Wardlow, B.D., Egbert, S.L., 2008. Large-area crop mapping using time-series MODIS $250 \mathrm{~m}$ NDVI data: An assessment for the US Central Great Plains. Remote Sens Environ 112, 1096-1116.

Wardlow, B.D., Egbert, S.L., Kastens, J.H., 2007. Analysis of time-series MODIS $250 \mathrm{~m}$ vegetation index data for crop classification in the US Central Great Plains. Remote Sens Environ 108, 290-310.

Wulder, M.A., White, J.C., Masek, J.G., Dwyer, J., Roy, D.P., 2011. Continuity of Landsat observations: Short term considerations. Remote Sens Environ 115, 747-751.

Xiao, X., Boles, S., Frolking, S., Salas, W., Moore, B., Li, C., He, L., Zhao, R., 2002.

Observation of flooding and rice transplanting of paddy rice fields at the site to landscape scales in China using VEGETATION sensor data. Int J Remote Sens 23, 3009-3022.

Xiao, X., Dorovskoy, P., Biradar, C.M., Bridge, E., 2011. A library of georeferenced photos from the field. Eos Trans. AGU 92.

Xiao, X.M., Boles, S., Frolking, S., Li, C.S., Babu, J.Y., Salas, W., Moore, B., 2006. Mapping paddy rice agriculture in South and Southeast Asia using multi-temporal MODIS images. Remote Sens Environ 100, 95-113.

Xiao, X.M., Boles, S., Liu, J.Y., Zhuang, D.F., Frolking, S., Li, C.S., Salas, W., Moore, B., 2005. Mapping paddy rice agriculture in southern China using multi-temporal MODIS images. Remote Sens Environ 95, 480-492.

Xiao, X.M., Braswell, B., Zhang, Q.Y., Boles, S., Frolking, S., Moore, B., 2003. Sensitivity of vegetation indices to atmospheric aerosols: continental-scale observations in Northern Asia. Remote Sens Environ 84, 385-392.

Yan, X., Akiyama, H., Yagi, K., Akimoto, H., 2009. Global estimations of the inventory and mitigation potential of methane emissions from rice cultivation conducted using the 2006 Intergovernmental Panel on Climate Change Guidelines. Global Biogeochem Cy 23.

Yan, X.Y., Ohara, T., Akimoto, H., 2003. Development of region-specific emission factors and estimation of methane emission from rice fields in the East, Southeast and South Asian countries. Glob Chang Biol 9, 237-254.

Yang, S.B., Shen, S.H., Li, B.B., Le Toan, T., He, W., 2008. Rice mapping and monitoring using ENVISAT ASAR data. Ieee Geosci Remote S 5, 108-112.

Yisok, O., Suk-Young, H., Yunjin, K., Jin-Young, H., Yi-Hyun, K., 2009. Polarimetric Backscattering Coefficients of Flooded Rice Fields at L- and C-Bands: Measurements, Modeling, and Data Analysis. Geoscience and Remote Sensing, IEEE Transactions on 47, 2714-2721.

Yu, L., Wang, J., Clinton, N., Xin, Q., Zhong, L., Chen, Y., Gong, P., 2013. FROM-GC: 30 m global cropland extent derived through multisource data integration. Int J Digit Earth 6, 521-533.

Zhang, G.L., Xiao, X.M., Dong, J.W., Kou, W.L., Jin, C., Qin, Y.W., Zhou, Y.T., Wang, J., Biradar, C., 2015. Mapping paddy rice planting areas through time series analysis of MODIS thermal and surface reflectance images. ISPRS for Photogrammetry and Remote Sensing 106, 157-171.

Zhang, Y., Wang, C.Z., Wu, J.P., Qi, J.G., Salas, W.A., 2009. Mapping paddy rice with multitemporal ALOS/PALSAR imagery in southeast China. Int J Remote Sens 30, 63016315. 
Zhang, Z., Wang, X., Zhao, X., Liu, B., Yi, L., Zuo, L., Wen, Q., Liu, F., Xu, J., Hu, S., 2014. A 2010 update of National Land Use/Cover Database of China at 1:100000 scale using medium spatial resolution satellite images. Remote Sens Environ 149, 142-154.

Zhong, L.H., Gong, P., Biging, G.S., 2014. Efficient corn and soybean mapping with temporal extendability: A multi-year experiment using Landsat imagery. Remote Sens Environ $140,1-13$. 
Table 1: A literature summary of existed studies using the reflectance data and image statistic-based paddy rice mapping approaches

\begin{tabular}{|c|c|c|c|c|c|c|c|}
\hline \multicolumn{8}{|c|}{ (Category One) } \\
\hline ID & Refs. & Sensor used & $\begin{array}{c}\text { Variables } \\
\text { used }\end{array}$ & Phases of Data Used & Methods & Study area & $\begin{array}{c}\text { Accur } \\
\text { acy }\end{array}$ \\
\hline 1 & $\begin{array}{l}\text { (Mccloy et al., } \\
\text { 1987) }\end{array}$ & Landsat MSS & $\begin{array}{l}\text { Band } \\
\text { reflectance }\end{array}$ & $\begin{array}{l}\text { Multi images from the establishment (Nov- } \\
\text { Jan) and growing phases (Feb) }\end{array}$ & MLC, VC & $\begin{array}{l}\text { SW of New South } \\
\text { Wales }\end{array}$ & $>87 \%$ \\
\hline 2 & $\begin{array}{l}\text { (Rao and Rao, } \\
\text { 1987) }\end{array}$ & Landsat MSS & $\begin{array}{c}\text { Band } \\
\text { reflectance }\end{array}$ & Multi images in Kharif (Rabi) season & VI & Case regions in India & $>90 \%$ \\
\hline 3 & $\begin{array}{l}\text { (Panigrahy and } \\
\text { Parihar, 1992) }\end{array}$ & Landsat TM & $\begin{array}{c}\text { Band } \\
\text { reflectance }\end{array}$ & $\begin{array}{c}\text { Single image on Oct } 17 \text { (middle Kharif } \\
\text { Season) }\end{array}$ & MLC & Case regions in India & $>78 \%$ \\
\hline 4 & $\begin{array}{c}\text { (Tennakoon et al., } \\
\text { 1992) }\end{array}$ & Landsat TM & $\begin{array}{c}\text { Band } \\
\text { reflectance }\end{array}$ & $\begin{array}{c}\text { Multi images from Seedling and Ripening } \\
\text { stages }\end{array}$ & MLC & $\begin{array}{l}\text { Case region in } \\
\text { Thailand }\end{array}$ & $>88 \%$ \\
\hline 5 & $\begin{array}{l}\text { (Fang et al., } \\
1998)\end{array}$ & $\begin{array}{c}\text { Landsat TM, } \\
\text { NOAA AVHRR }\end{array}$ & $\begin{array}{c}\text { Band } \\
\text { reflectance }\end{array}$ & All available images, no phase specific & MLC & Hubei, China & $91.6 \%$ \\
\hline 6 & (Fang, 1998) & Landsat TM & $\begin{array}{c}\text { Band } \\
\text { reflectance }\end{array}$ & $\begin{array}{c}\text { Single image in early growing season } \\
\text { before transplanting }\end{array}$ & $\begin{array}{l}\text { Unsupervised } \\
\text { classification }\end{array}$ & Hubei, China & $>81 \%$ \\
\hline 7 & $\begin{array}{c}\text { (Turner and } \\
\text { Congalton, 1998) }\end{array}$ & SPOT XS & $\begin{array}{l}3 \text { images } \\
\text { (G/R/NIR) }\end{array}$ & $\begin{array}{l}\text { Multi images from pre- and first half of } \\
\text { flood }\end{array}$ & $\begin{array}{c}\text { Hybrid } \\
\text { classification }\end{array}$ & West Africa & $70 \%$ \\
\hline 8 & $\begin{array}{c}\text { (Kurosu et al., } \\
\text { 1997) }\end{array}$ & ERS-1 C-band & $\sigma^{0}$ & Multi images from June to September 1992 & MLC & $\begin{array}{c}\text { Ohgata-mura area, } \\
\text { Japan }\end{array}$ & $93 \%$ \\
\hline 9 & $\begin{array}{l}\text { (Okamoto and } \\
\text { Kawashima, } \\
\text { 1999) }\end{array}$ & Landsat, JERS-1 & $\begin{array}{l}\text { Reflectance } \\
\quad \text { and } \sigma^{0}\end{array}$ & $\begin{array}{l}\text { Landsat data in dry season, JERS-1 in } \\
\text { planting season }\end{array}$ & TS & Indramayu, Indonesia & --- \\
\hline 10 & $\begin{array}{l}\text { (Le Toan et al., } \\
\text { 1997) }\end{array}$ & ERS-1 C-band & $\sigma^{0}$ & Multi images in growing season & TS & $\begin{array}{l}\text { Two sites in Indonesia } \\
\text { and Japan }\end{array}$ & --- \\
\hline
\end{tabular}

Note: AVHRR — Advanced Very High Resolution Radiometer; DVI—difference vegetation index; EVI—enhanced vegetation index; IPVIinfrared percentage vegetation index; LSWI-land surface water index; MODIS - Moderate Resolution Imaging Spectroradiometer; NDBInormalized build-up index; NDVI - normalized difference vegetation index; NOAA - National Oceanic and Atmospheric Administration; RGVI — rice growth vegetation index; RVI—ratio vegetation index; SAVI—soil adjusted vegetation index; SPOT-5 HRG—Satellite Pour l'Observation de la Terre 5 High Resolution Geometric; SPOT VGT-Satellite Pour l'Observation de la Terre (SPOT) vegetation; TVItransformed vegetation index. $\sigma^{0}$-Backscattering coefficient.

Abbreviations for the Methods: Maximum Likelihood Classification (MLC); Visual interpretation (VI), Threshold-based segmentation (TS) Accuracy information is just a general reference considering the different definitions and variables used, and multiple strategy comparison in one study. Some values were the overall accuracy, while others are minimum accuracy values of producer and user accuracies. 
Table 2: A literature summary of existed studies using the VI and enhanced image statistic-based paddy rice mapping approaches (Category Two).

\begin{tabular}{|c|c|c|c|c|c|c|c|}
\hline ID & Refs. & Sensor used & Variables used & Phases of Data Used & Methods & Study area & Accuracy \\
\hline 11 & $\begin{array}{l}\text { (Shao et al., } \\
\text { 2001) }\end{array}$ & $\begin{array}{l}\text { RADARSAT-1 C-band } \\
\text { with HH polarization }\end{array}$ & $\sigma^{0}$ & $\begin{array}{c}\text { Multi images in } \\
\text { transplanting, flowering } \\
\text { and harvest stages }\end{array}$ & NN & $\begin{array}{l}\text { Two counties } \\
\text { in China }\end{array}$ & $97 \%$ \\
\hline 12 & $\begin{array}{l}\text { (Oguro et al., } \\
2001)\end{array}$ & $\begin{array}{l}\text { Landsat5 TM, SPOT2 } \\
\text { HRV, SPOT4 HRVIR, } \\
\text { RADARSAT-1 }\end{array}$ & $\begin{array}{l}\text { NDVI, EVI, EVI- } \\
\quad \text { NDVI, } \sigma^{0}\end{array}$ & $\begin{array}{l}\text { Multi optical images in } \\
\text { growing season; two } \\
\text { SAR images before and } \\
\text { just after planting }\end{array}$ & MLC & $\begin{array}{l}\text { Higashi- } \\
\text { Hiroshima } \\
\text { City, Japan }\end{array}$ & --- \\
\hline 13 & $\begin{array}{l}\text { (Niel and } \\
\text { McVicar, } \\
\text { 2003) }\end{array}$ & Landsat ETM & NDVI and $D_{1650 \mathrm{~nm}}$ & $\begin{array}{l}\text { Multi images in growing } \\
\text { season }\end{array}$ & $\mathrm{TS}$ & $\begin{array}{l}\text { southern New } \\
\text { South Wales }\end{array}$ & --- \\
\hline 14 & $\begin{array}{l}\text { (Chen and } \\
\text { McNairn, } \\
\text { 2006) }\end{array}$ & $\begin{array}{l}\text { RADARSAT-1(C-band } \\
\text { with HH polarization) }\end{array}$ & $\sigma^{0}$ & $\begin{array}{l}\text { Multi images in dry and } \\
\text { wet seasons }\end{array}$ & $\begin{array}{c}\mathrm{NN}, \mathrm{CC}, \mathrm{CC}+\mathrm{NN}, \\
\mathrm{MLC}\end{array}$ & $\begin{array}{l}\text { Two areas in } \\
\text { Philippine }\end{array}$ & $>96 \%$ \\
\hline 15 & $\begin{array}{l}\text { (Zhang et al., } \\
\text { 2009) }\end{array}$ & ALOS/PALSAR & $\sigma^{0}$ & $\begin{array}{c}\text { Multi images in } \\
\text { transplanting, vegetative } \\
\text { and heading stages }\end{array}$ & SVM & $\begin{array}{l}\text { An area in } \\
\text { China }\end{array}$ & $>70 \%$ \\
\hline 16 & $\begin{array}{l}\text { (Tan et al., } \\
\text { 2007) }\end{array}$ & $\begin{array}{l}\text { RADARSAT-1 (C-band } \\
\text { with HH polarization) }\end{array}$ & $\sigma^{0}$ & $\begin{array}{l}\text { Multi images in } \\
\text { vegetative, reproductive, } \\
\text { and ripening stages }\end{array}$ & $\mathrm{ED}+\mathrm{SVM}$ & $\begin{array}{l}\text { An area in } \\
\text { Malaysia }\end{array}$ & $95 \%$ \\
\hline 17 & $\begin{array}{c}\text { (Pan et al., } \\
2010)\end{array}$ & Landsat TM & NDVI,NDWI,NDSI & $\begin{array}{l}\text { Multi images from } \\
\text { transplant to harvest }\end{array}$ & ISODATA & $\begin{array}{c}\text { Shaoxing, } \\
\text { China }\end{array}$ & $>61 \%$ \\
\hline 18 & $\begin{array}{l}\text { (Thi et al., } \\
\text { 2012) }\end{array}$ & SPOT-VGT & NDVI & $\begin{array}{c}\text { Time series images from } \\
\text { entire year }\end{array}$ & ISODATA & Mekong delta & $94 \%$ \\
\hline 19 & $\begin{array}{l}\text { (Li et al., } \\
\text { 2014) }\end{array}$ & $\mathrm{HJ}-1 \mathrm{~A} / \mathrm{B}$ & B/G/R/NIR bands & $\begin{array}{l}\text { Multi images in growing } \\
\text { season }\end{array}$ & $\begin{array}{l}\text { SVM for pure rice, rice } \\
\text { area fraction index for } \\
\text { mixed pixels }\end{array}$ & Hunan, China & $>97 \%$ \\
\hline
\end{tabular}

Note: Change detection (CC), entropy decomposition (ED) 
Table 3: A literature summary of existed studies using the VI or RADAR backscatter-based temporal analysis approaches (Category Three).

\begin{tabular}{|c|c|c|c|c|c|c|c|}
\hline ID & Refs. & Sensor used & $\begin{array}{c}\text { Variables } \\
\text { used }\end{array}$ & Phases of Data Used & Methods & Study area & Accuracy \\
\hline 20 & $\begin{array}{c}\text { (Chen et al., } \\
\text { 2011b) }\end{array}$ & $\mathrm{HJ}-1 \mathrm{~A} / \mathrm{B}$ & NDVI & $\begin{array}{l}\text { Multi images in early } \\
\text { rice growing season }\end{array}$ & TA & $\begin{array}{l}\text { Guangdong, } \\
\text { China }\end{array}$ & Карра $=0.71$ \\
\hline 21 & $\begin{array}{c}\text { (Oguro et al., } \\
2003)\end{array}$ & Landsat 5 and 7 & NDVI, EVI & $\begin{array}{l}\text { Two images after } \\
\text { transplanting }\end{array}$ & Multi-temporal analysis & $\begin{array}{l}\text { Hiroshima, } \\
\text { Japan }\end{array}$ & --- \\
\hline 22 & (Son et al., 2013) & MODIS & EVI & $\begin{array}{c}\text { Time series images in } \\
\text { entire year }\end{array}$ & TA & $\begin{array}{c}\text { Mekong Delta, } \\
\text { Vietnam }\end{array}$ & $>80 \%$ \\
\hline 23 & $\begin{array}{c}\text { (Nuarsa et al., } \\
\text { 2012) }\end{array}$ & MODIS & $\begin{array}{c}\text { NDVI, RVI, } \\
\text { SAVI }\end{array}$ & $\begin{array}{c}\text { Daily data in entire } \\
\text { year }\end{array}$ & TA & Bali, Indonesia & $88 \%$ \\
\hline 24 & $\begin{array}{c}\text { (Gumma et al., } \\
\text { 2011) }\end{array}$ & MODIS & NDVI & $\begin{array}{c}\text { Time series images in } \\
\text { entire year }\end{array}$ & $\begin{array}{c}\text { A suite of methods (SMT, DT } \\
\text { etc) }\end{array}$ & South Asia & $80 \%$ \\
\hline 25 & $\begin{array}{c}\text { (Gumma et al., } \\
\text { 2014) }\end{array}$ & MODIS & NDVI & $\begin{array}{c}\text { Time series images in } \\
\text { entire year }\end{array}$ & $\begin{array}{c}\text { A suite of methods (SMT, DT } \\
\text { etc) }\end{array}$ & Bangladesh & $>78 \%$ \\
\hline 26 & $\begin{array}{l}\text { (Nelson et al., } \\
\text { 2014) }\end{array}$ & $\begin{array}{c}\text { CSK, COSMO- } \\
\text { SkyMed; TSX, } \\
\text { TerraSAR-X } \\
\end{array}$ & $\sigma^{0}$ & $\begin{array}{l}\text { Multi images in } \\
\text { growing season }\end{array}$ & TA & $\begin{array}{l}13 \text { footprints in } \\
\text { Asia }\end{array}$ & $>85 \%(\mathrm{OA})$ \\
\hline 27 & $\begin{array}{l}\text { (Chen et al., } \\
\text { 2011a) }\end{array}$ & MODIS & NDVI & $\begin{array}{c}\text { Time series images in } \\
\text { entire year }\end{array}$ & LMM+EMD & $\begin{array}{c}\text { Mekong Delta, } \\
\text { Vietnam }\end{array}$ & $\begin{array}{l}71.6 \% \\
(\mathrm{OA})\end{array}$ \\
\hline 28 & $\begin{array}{l}\text { (Kamthonkiat et } \\
\text { al., 2005) }\end{array}$ & SPOT VGT & NDVI & $\begin{array}{l}\text { Time series images in } \\
\text { entire year }\end{array}$ & $\begin{array}{c}\text { Peak detector algorithm to } \\
\text { separate rain-fed and irrigated } \\
\text { rice }\end{array}$ & Thailand & $89 \%$ \\
\hline 29 & $\begin{array}{l}\text { (Bouvet and Le } \\
\text { Toan, 2011) }\end{array}$ & ENVISAT ASAR & $\sigma^{0}$ & $\begin{array}{l}21 \text { images from } \\
\text { growing season }\end{array}$ & $\mathrm{TS}$ & Mekong Basin & $>81 \%$ \\
\hline 30 & $\begin{array}{l}\text { (Chen et al., } \\
\text { 2007) }\end{array}$ & $\begin{array}{l}\text { ENVISAT ASAR C- } \\
\text { band }\end{array}$ & $\sigma^{0}$ & $\begin{array}{l}\text { Multiple images in } \\
\text { early rice growing } \\
\text { season }\end{array}$ & TS & $\begin{array}{l}\text { Guangdong, } \\
\text { China }\end{array}$ & $>77 \%$ \\
\hline 31 & $\begin{array}{l}\text { (Yang et al., } \\
\text { 2008) }\end{array}$ & $\begin{array}{c}\text { ENVISAT/ASAR } \\
\text { VV/HH }\end{array}$ & $\sigma^{0}$ & $\begin{array}{l}\text { Single image in } \\
\text { middle growing } \\
\text { season }\end{array}$ & $\mathrm{TS}$ & Jiangsu, China & $81 \%(\mathrm{OA})$ \\
\hline 32 & (Li et al., 2012a) & RADARSAT-2 & $\sigma^{0}$ & $\begin{array}{l}\text { Multi images in } \\
\text { growing season }\end{array}$ & SVM+PD & Guizhou, China & $>91 \%$ \\
\hline 33 & $\begin{array}{c}\text { (Mosleh and } \\
\text { Hassan, 2014) }\end{array}$ & MODIS & NDVI & $\begin{array}{l}\text { Multiple images in } \\
\text { growing season }\end{array}$ & ISODATA+TS & Bangladesh & $\begin{array}{c}\mathrm{R}^{2}=0.69- \\
0.89\end{array}$ \\
\hline 34 & (Jain et al., 2013) & Landsat, MODIS & NDVI, EVI & $\begin{array}{l}\text { Multiple images in } \\
\text { entire year }\end{array}$ & TS, TMA, Peak method & $\begin{array}{l}\text { Northwest and } \\
\text { central India }\end{array}$ & --- \\
\hline
\end{tabular}

Note: Spectral matching techniques (SMT) Decision tree (DT) Linear Mixture Model (LMM), Empirical Mode Decomposition (EMD) 
Table 4: A literature summary of existed studies using the phenology-based paddy rice mapping approaches, based on remote sensing recognition of key growth phases (Category Four).

\begin{tabular}{|c|c|c|c|c|c|c|c|}
\hline ID & Refs. & Sensor used & Variables used & Phases of Data Used & Methods & Study area & Accuracy \\
\hline 35 & $\begin{array}{l}\text { (Xiao et al., } \\
\text { 2005) }\end{array}$ & MODIS & $\begin{array}{l}\text { NDVI, EVI, } \\
\text { LSWI, NDSI }\end{array}$ & $\begin{array}{l}\text { Time series images in entire } \\
\text { year }\end{array}$ & PA & Southern China & --- \\
\hline 36 & $\begin{array}{l}\text { (Xiao et al., } \\
\text { 2006) }\end{array}$ & MODIS & $\begin{array}{l}\text { NDVI, EVI, } \\
\text { LSWI, NDSI }\end{array}$ & $\begin{array}{l}\text { Time series images in entire } \\
\text { year }\end{array}$ & PA & $\begin{array}{c}\text { South and } \\
\text { Southeast Asia }\end{array}$ & --- \\
\hline 37 & $\begin{array}{l}\text { (Feng et al., } \\
\text { 2011) }\end{array}$ & MODIS & $\begin{array}{l}\text { NDVI, EVI, } \\
\text { LSWI }\end{array}$ & $2007-2008$ & & Panjin, China & $89.5 \%$ \\
\hline 38 & $\begin{array}{l}\text { (Sakamoto et } \\
\text { al., 2009) }\end{array}$ & MODIS & $\begin{array}{l}\text { EVI, LSWI, } \\
\text { DVEL (EVI- } \\
\text { LSWI) } \\
\end{array}$ & $\begin{array}{c}\text { Time series images in entire } \\
\text { year }\end{array}$ & $\mathrm{TS}$ & $\begin{array}{c}\text { Part of Mekong } \\
\text { delta }\end{array}$ & --- \\
\hline 39 & $\begin{array}{c}\text { (Sun et al., } \\
\text { 2009) }\end{array}$ & MODIS & EVI, LSWI & $\begin{array}{c}\text { Time series images in entire } \\
\text { year }\end{array}$ & PA & China & $>73 \%$ \\
\hline 40 & $\begin{array}{l}\text { (Bridhikitti } \\
\text { and } \\
\text { Overcamp, } \\
\text { 2012) }\end{array}$ & MODIS & $\begin{array}{l}\text { EVI, NDVI, } \\
\text { LSWI, NDSI, } \\
\text { FT (flooding } \\
\text { and } \\
\text { transplanting) }\end{array}$ & $\begin{array}{c}\text { Time series images in entire } \\
\text { year }\end{array}$ & $\mathrm{TS}$ & Southeast Asia & --- \\
\hline 41 & $\begin{array}{c}\text { (Jeong et al., } \\
\text { 2012) }\end{array}$ & MODIS, SAR & LSWI, EVI & $\begin{array}{c}\text { Time series images in entire } \\
\text { year }\end{array}$ & Variable TS & Yedang, Korea & --- \\
\hline 42 & $\begin{array}{c}\text { (Peng et al., } \\
\text { 2011) }\end{array}$ & MODIS & LSWI, EVI & $\begin{array}{c}\text { Time series images in entire } \\
\text { year }\end{array}$ & PA & Hunan, China & $>84 \%$ \\
\hline 43 & $\begin{array}{l}\text { (Torbick et al., } \\
\text { 2011) }\end{array}$ & $\begin{array}{l}\text { PALSAR, } \\
\text { ScanSAR, } \\
\text { MODIS }\end{array}$ & $\begin{array}{c}\sigma^{0}, \mathrm{LSWI}, \mathrm{EVI}, \\
\text { NDVI }\end{array}$ & $\begin{array}{c}\text { Multiple images in entire } \\
\text { year }\end{array}$ & PA & $\begin{array}{c}\text { Sacramento Valley, } \\
\text { USA }\end{array}$ & $95 \%$ \\
\hline 44 & $\begin{array}{l}\text { (Shiu et al., } \\
\text { 2012) }\end{array}$ & FORMOSAT-2 & $\begin{array}{c}\text { Band } \\
\text { reflectance } \\
(\mathrm{R} / \mathrm{G} / \mathrm{B} / \mathrm{NIR})\end{array}$ & $\begin{array}{c}\text { Multi images in } \\
\text { transplanting and tillering } \\
\text { stages }\end{array}$ & $\begin{array}{l}\text { ISODATA+MLC, Object- } \\
\text { based and pixel-based }\end{array}$ & Taiwan & $>82 \%$ \\
\hline
\end{tabular}

Note: Phenology-based Algorithm (PA), Temporal Mixture Analysis (TMA), Polarization Decomposition (PD) 